\title{
Preliminary investigation of a diverse megafossil floral assemblage from the middle Miocene of southern Mississippi, USA
}

\author{
Daniel M. McNair, Debra Z. Stults, Brian Axsmith, \\ Mac H. Alford, and James E. Starnes
}

\begin{abstract}
Our understanding of Miocene floras in eastern North America is hampered by the rarity of megafossil sites. An early report from the middle Miocene Hattiesburg Formation in Mississippi included palms and Ulmus. A later report listed Taxodium, Salix, either Morus or Celtis, and monocot fragments. The floral assemblage described here was recently recovered from along the Bouie River in southern Mississippi. Ferns are represented by complete Salvinia specimens including attached sporocarps, Woodwardia, and Osmunda. Conifers are represented by branchlets of Taxodium. Angiosperms include leaves attributable to the Lauraceae. Platanus is known from leaves, stipules, and fruits. Leaflets of Sambucus are common. Cercis is recognized from leaves with palmate venation and pulvini. Leaves of Quercus sections Lobatae and Quercus have been recovered. The Juglandaceae include fruits of Juglans and two species of Carya. Morus, Populus, and Salix leaves have been recovered. Of particular biogeographical interest is a seed of Sargentodoxa, which is the first record from the southeastern coastal plain of this current Chinese endemic. Monocots include Cyperus and two types of palm, including one with armed petioles. The first vegetative fossils of Lemna from North America have been identified. Because most of the fossils are related to plants still found in the region today, the climate was probably similar to that of the modern central Gulf Coastal Plain. This flora is now one of the most extensively known in the Neogene of southeastern North America and helps to fill a major gap in our understating of Miocene plant evolution.
\end{abstract}

Daniel M. McNair. School of Biological, Environmental, and Earth Sciences, University of Southern Mississippi, 118 College Drive \#5018, Hattiesburg, Mississippi 39406, USA. danielmcnair@gmail.com Debra Z. Stults. Biology Department, University of South Alabama, 5871 University Drive North, Room 124, Mobile, Alabama 36688, USA. dstults@health.southalabama.edu Brian Axsmith. Biology Department, University of South Alabama, University of South Alabama, 5871 University Drive North, Room 124, Mobile, Alabama 36688, USA. baxsmith@southalabama.edu

\footnotetext{
McNair, Daniel, Stults, Debra Z., Axsmith, Brian, Alford, Mac H., and Starnes, James E. 2019. Preliminary investigation of a diverse megafossil floral assemblage from the middle Miocene of southern Mississippi, USA. Palaeontologia Electronica 22.2.40A 1-30. https://doi.org/10.26879/906

palaeo-electronica.org/content/2019/2540-miocene-plants-of-mississippi

Copyright: July 2019 Paleontological Society.

This is an open access article distributed under the terms of Attribution-NonCommercial-ShareAlike 4.0 International (CC BY-NC-SA

4.0 ), which permits users to copy and redistribute the material in any medium or format, provided it is not used for commercial

purposes and the original author and source are credited, with indications if any changes are made.

creativecommons.org/licenses/by-nc-sa/4.0/
} 
Mac H. Alford. School of Biological, Environmental, and Earth Sciences, University of Southern Mississippi, 118 College Drive \#5018, Hattiesburg, Mississippi 39406, USA. mac.alford@usm.edu James E. Starnes. RPG, Mississippi Departmental of Environmental Quality, Mississippi Office of Geology, 700 North State Street, Jackson, Mississippi 39202, USA. jstarnes@mdeq.ms.gov

Keywords: Gulf Coast; Hattiesburg Formation; Lemna; fossil palms; Salvinia; Sargentodoxa

Submission: 12 July 2018. Acceptance: 29 April 2019.

\section{INTRODUCTION}

The Miocene Epoch is poorly represented in the megafossil plant record of the eastern United States, and the few scattered sites that have been described are generally not temporally well constrained. This is unfortunate, as the Miocene is widely considered a critical time in the evolution of modern plant communities, including such events as the rise to ecological dominance of $\mathrm{C}_{4}$ dominated grasslands (Bouchenak-Khelladi et al., 2014), the extirpation of several "Asian" taxa from North America (Manchester, 1999), and continued post-Eocene climatic deterioration (Graham, 2010). The only substantial site in the northeastern USA is the stratigraphically isolated Brandon Lignite in Vermont of probable early Miocene age (Tiffney, 1994). In the Mid-Atlantic region, a flora from the Brandywine Formation of Maryland was briefly documented (McCartan et al., 1990), but detailed descriptions are still ongoing (Stults et al., 2011). In the southeast, work on sinkhole floras from the late Miocene to early Pliocene of eastern Tennessee are now comparatively well documented (Gong et al., 2010). On the Gulf Coastal Plain, work on the middle Miocene Alum Bluff flora of the Florida Panhandle has documented a small megafossil flora (Corbett, 2004), expanding on earlier work by Berry (1916a).

Within Berry's (1916a) account of the Alum Bluff paleoflora is a brief description of an assemblage from Hattiesburg, Mississippi, that he asserted was coeval with Alum Bluff, and included a poorly preserved palm (Sabalites apalachicolensis) and leaves attributed to Ulmus. Another small flora from the Hattiesburg Formation was described from fossils recovered during a groundwater survey (Brown, 1944). The plants were identified by the paleobotanist Roland Brown as probable Taxodium, Salix, either Morus or Celtis, and unidentified monocot fragments. None of the plant fossils mentioned in these reports were figured or described in any detail, and subsequent attempts at finding more specimens from these localities have not been successful.

Recent discoveries of fossil plants from previously unexplored exposures of the Hattiesburg Formation along the Bouie River (also commonly known as the Bowie River) in southern Mississippi are providing important information on plant diversity from this otherwise poorly known interval (Figures 1-3). Such sites are critical for expanding our understanding of plant evolution in this biodiverse part of North America. The following account should be considered preliminary, as several of the taxa require additional study and separate detailed publications. However, most components of the flora are presented below in considerable detail.

\section{GEOLOGICAL SETTING}

The central Gulf Coastal Plain, including the Hattiesburg area, contains thick sequences of $\mathrm{NeO}-$ gene sediments, but their delineation has been historically controversial. As noted by Dockery and Thompson (2016), the sequence is mostly a monotonous series of fluvial and deltaic units, resulting in poorly constrained formational boundaries (Figure 3). In addition, extensive surface exposures are uncommon and are poor in diagnostic marine index fossils, making it difficult to place the Hattiesburg plant fossils in a precise stratigraphic and temporal context. Nevertheless, we propose that the site occurs in the uppermost Hattiesburg Formation and is of probable middle Miocene age based on several lines of evidence presented below.

The fossil site (MS. 18.001) occurs along both sides of the Bouie River, where the river makes a hard turn to the north just below the Glendale Avenue bridge on the northern border of the city of Hattiesburg, Mississippi (N 31.34969; W 89.30537) (Figure 2.2). Here, the river cut exposes about seven vertical meters of section along the eastern bank, with lower exposures present to the west (Figure 1.3). The site is attributed to the upper Hattiesburg Formation based on nearby well log data correlated with deeper well logs, which also 


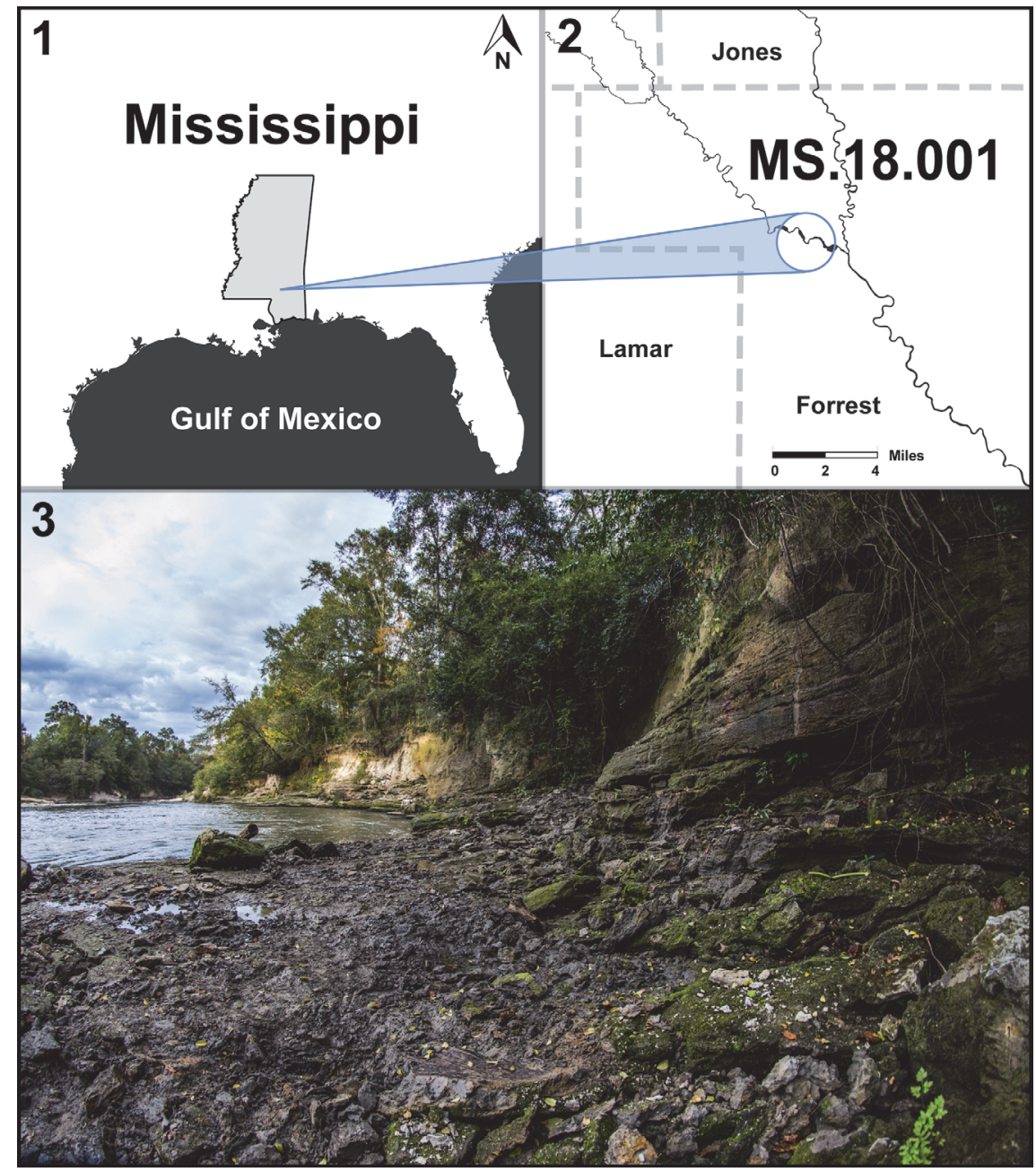

FIGURE 1. Maps and photograph of the study site (MS.18.001). 2, Index maps showing the outline of the state of Mississippi and the location of the site (MS. 18.001). 3, Field photograph looking north downstream showing the Bouie River cutting through the Hattiesburg Formation.

includes the stratigraphic relationship to underlying units (Figure 2).

The Hattiesburg Formation consists of thick channel sands separated by silty to fine-sandy clays in the middle, alluvial phase of the Grand Gulf Group. This portion of the post-Vicksburg prograding deltaic wedge overlies the Catahoula Formation of late Oligocene to early Miocene age (Foster, 1941) (Figures 2.1, 3). The Bouie River site is typical of the non-marine finer-grained sediments of the Grand Gulf Section. It consists of pyritic, gray-green colored, thinly-bedded to laminated alternating clays, silts, and fine-grained sands. This repetitive sequence is slightly carbonaceous to highly lignitic, with well-preserved fossil leaves and leaf hash along fissile partings and large, imbedded, lignitized logs. The depositional setting is likely an interfluvial over-bank deposit in the lower distributary portion of a coastal river. The site is projected downdip to be not far below the gradational contact with the overlying Pascagoula Formation (Figure 3).

A middle Miocene age designation is proposed for the Bouie River site based on correlations of this section to marine equivalents offshore. Also supporting this designation is a sparse collection of vertebrate material reported from other nearby Hattiesburg Formation outcrops. A strongly age-diagnostic example is a Teleoceras medicornutum tibia that was found as float in association with a fossil llama proximal phalanx on a Hattiesburg Formation outcrop on the Middle Fork of the Homochitto River near Meadville in Franklin County, Mississippi (Dockery and Thompson, 2016). Teleoceras medicornutum is a Barstovian, middle Miocene rhinoceros previously known from 


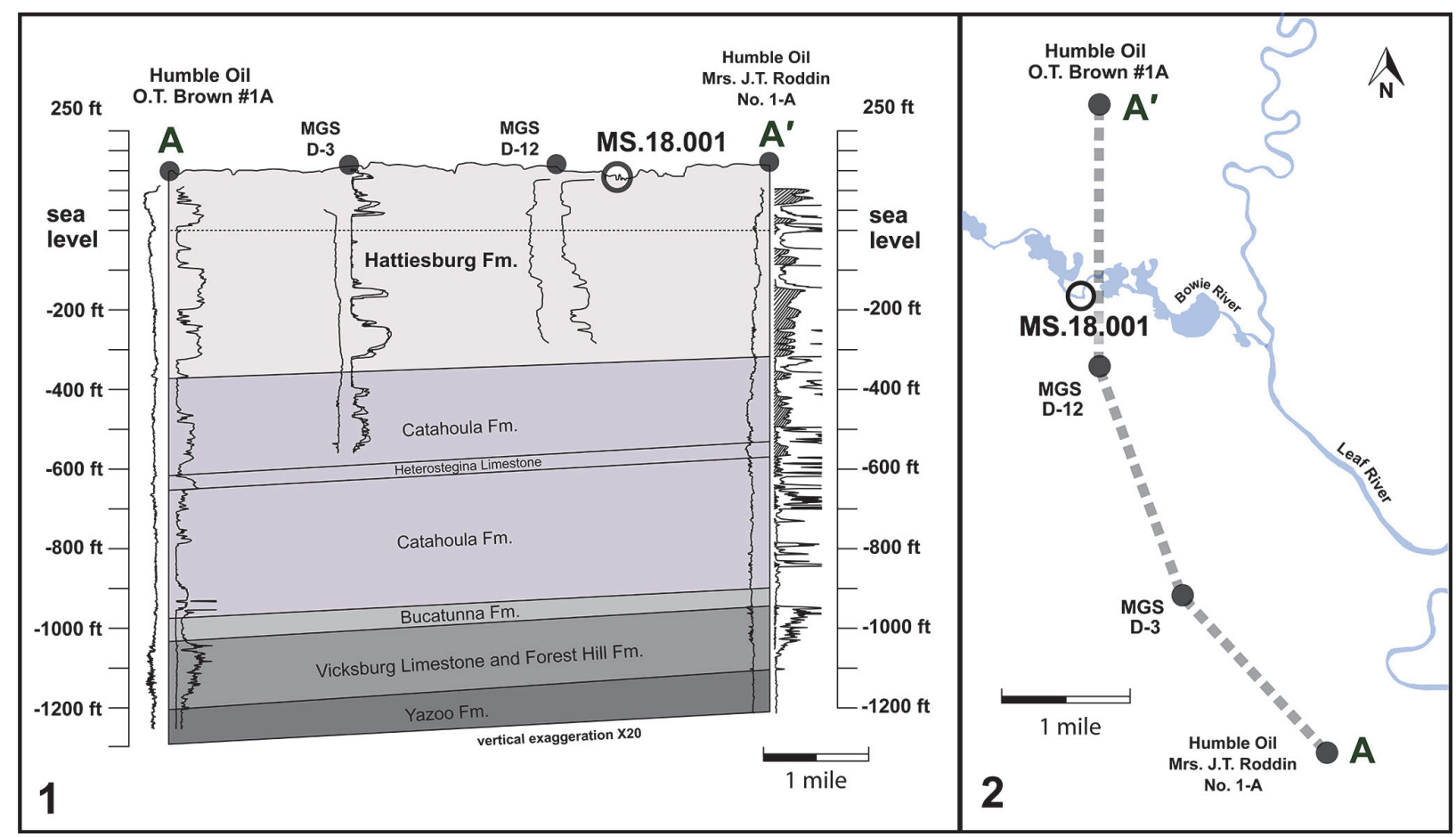

FIGURE 2. Structural cross section and stratigraphic position. 1, Structural cross section data showing the uppermost Oligocene at the top of the Heterostegina Limestone. The section above that unit is attributed to the Miocene. 2, Corresponding map of $A$ to $A^{\prime}$ well sites close to the study site (MS. 18.001).

the Fleming Formation, Burkeville fauna of the Gulf Coastal Plain of Texas (Prothero and Manning, 1987). Overlying the Hattiesburg Formation in Mississippi is the Pascagoula Formation, which contains the index fossil Rangia johnsoni, a late Miocene bivalve mollusk. The Pascagoula Formation also contains a sparse late Miocene vertebrate fauna in Stone County and Amite County, Mississippi, that may be correlative to the better documented Mauvilla Fauna of southern Alabama (Hulbert and Whitmore, 2006).

\section{MATERIALS AND METHODS}

All of the described and figured specimens were collected from the Bouie River site in Hattiesburg, Mississippi (N 31.34969; W 89.30537), and are curated in the Mississippi Museum of Natural Science (MMNS) Paleontology Collection in Jackson, Mississippi. The descriptions are primarily based upon the figured specimens and include MMNS PB-82, 83, 84, 85, 86; MMNS 87.1, 87.2; MMNS 88.1, 88.2, 88.3, 88.4, 89, 90, 91, 92, 93, $94,95,96,97,98,99,100,101,102,103,104$, $105.1,105.2,106,107,108$, and 109. Specimen numbers are also listed in the corresponding figure captions.
The fossils are mostly impressions and some compressions recovered by splitting the matrix in which they are contained. A few specimens are represented by relatively uncompressed, threedimensional seeds and fruits that emerged from the matrix when split. When needed, an assortment of needles and brushes was used to fully expose the plant organs. Fragmentary cuticles, when recoverable from the compressions, were obtained by maceration of the organic matter using various dilute concentrations of sodium hypochlorite. Specimens of wood consistent with the identifications here were examined and will be presented in a future publication.

Larger specimens were photographed on a copy stand using a Nikon D3200 digital SLR camera, with close-ups using a Tokina $100 \mathrm{~mm}$ lens. Micrographs were taken with a Zeiss Stemi 2000-C dissecting microscope on a Diagnostic Instruments boom stand, and a Zeiss Axio Imager 2 system. Salvinia sporocarp contents were obtained by removing them from the matrix surface with needles followed by mounting on stubs for SEM study using an FEI Quanta 200 environmental scanning electron microscope. The sporocarp contents were not sputter coated. 


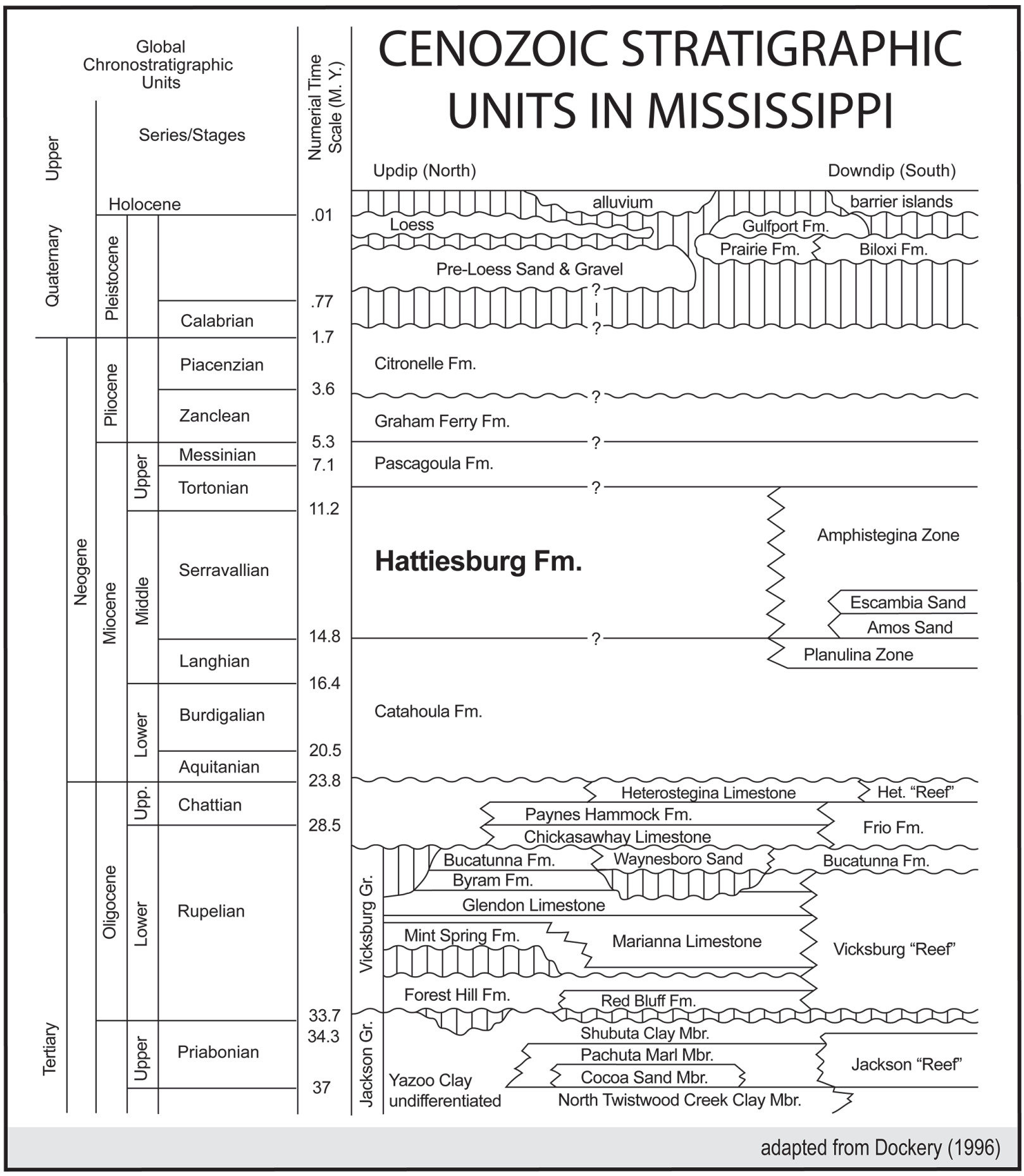

FIGURE 3. Select portion (uppermost Eocene through Holocene) of the stratigraphic units of Mississippi adapted from Dockery (1996). The Hattiesburg Formation is indicated in boldface. Data presented in this paper suggests a slightly older age (middle Miocene) for the upper part of the Hattiesburg Formation (see text for details).

The systematic identifications presented here are based primarily on herbarium reference material, living material, and various literature sources cited in the description section below. Classifications are based on Chase and Reveal (2009), along with the Angiosperm Phylogeny Group (APG) IV (2016), Smith et al. (2006), and Reveal (1992, 2012). However, for readability and accessibility, taxa are also organized under informal but 
widely-used groupings such as "ferns," "conifers," and "angiosperms."

Leaf morphological descriptions are based as far as possible on the Manual of Leaf Architecture (Ellis et al., 2009). Nearly all the fossils are assignable to extant families and genera. In some cases where multiple lines of evidence support it, they are identified to the species level. A "cf." designation preceding a name indicates that the fossil is a possible representative of the taxon, but more complete or better-preserved material is required for verification.

\section{SYSTEMATIC PALEOBOTANY}

\author{
Subclass POLYPODIIDAE Cronquist, Takht. and \\ Zimmerm., 1966 \\ Order OSMUNDALES Bromhead, 1838 \\ Family OSMUNDACEAE Martinov, 1820 \\ Genus OSMUNDA Linnaeus, 1753 \\ OSMUNDA sp. indet. cf. spectabilis Willdenow, \\ 1810 \\ Figure 4.1-2
}

Description. Two compressions and one impression fossil of sterile pinnules represent Osmunda. The pinnule apices are acute. A partial petiolule is visible at the basal end of the most complete pinnule (Figure 4.1). Approximately 10 teeth per $\mathrm{cm}$ occur along the thickened margin. From the pinnule mid-veins arise numerous, regularly-placed, closely-spaced lateral veins. Branching of the pinnule lateral veins occurs mostly near the mid-vein, less frequently midway to the margin, culminating in veinlets of the same gauge with parallel courses ending at the margin (Figure 4.2). The average distance between these parallel secondary veins is $332 \mu \mathrm{m}$.

Remarks. The fossil record of the Osmundaceae extends back to the Permian Period (Hewitson, 1962; Tidwell and Ash, 1994), and many fossil examples demonstrate remarkable morphological stasis over hundreds of millions of years (Miller, 1967; Phipps et al. 1998; Vavrek et al., 2006; Bomfleur, 2014). Currently, the family contains four genera: Leptopteris, Osmunda, Osmundastrum, and Todea (Metzgar et al., 2008). Within genus Osmunda are three subgenera, Claytosmunda, Osmunda, and Plenasium. One character that differentiates subgenus Osmunda from Claytosmunda and Plenasium is the presence bipinnate leaves, a feature recognized when the pinnule is connected to the costa by a slender petiolule. While a direct connection to the costa is not visible in the Hattiesburg Formation fossil, the presence of a partial slender petiolule and smoothly rounded petiole bases indicates a probable originally bipinnate frond like that of subgenus Osmunda species. Four species presently comprise subgenus Osmunda: O. regalis (European), O. japonica and O. lancea (southeastern Asia), and O. spectabilis (Western Hemisphere). Most authorities now accept that $O$. spectabilis is a separate species and not a variety or subspecies of $O$. regalis (Gray, 1856; Underwood, 1903; Löve and Löve, 1977; Arana and Ponce, 2015). Osmunda spectabilis occurs only in the Western Hemisphere, is phylogenetically distinct from the European $O$. regalis, and is contained within the clade including the Japanese species $O$. japonica and $O$. lancea (Metzgar et al., 2008; Arana and Ponce, 2015).

The Hattiesburg Formation fossils indicate affinity with the genus Osmunda (Cobb et al., 2005), and there are possible species level features when compared with similar extant forms of subgenus Osmunda. The pinnule lateral veins of $O$. japonica and $O$. regalis branch several times; $O$. lancea and $O$. spectabilis branch much less frequently (Hewiston, 1962), in accord with the Hattiesburg fossils. Our observations of living and herbarium material of $O$. spectabilis indicate lateral veins that branch nearer the midvein and exhibit a more uniform parallel course toward the margin (as in the Hattiesburg Formation fossils, and O. lancea), and a narrower distance between veinlets (Imaichi and Kato, 1992). Because the fossils occur within the extant range of $O$. spectabilis and considering the extremely long temporal range of many Osmunda species, we suggest that it is a representative of that species rather than $O$. lancea or an extinct form. At this point, affinity with $\mathrm{Tel}-$ matoblechnum serrulatum (Blechnaceae) cannot be entirely ruled out due to convergence in leaf architecture. More complete material will be required to resolve the exact affinities of this fern.

Order POLYPODIALES Mett. ex A.B. Frank, 1877

Family BLECHNACEAE Newman, 1844

Genus WOODWARDIA Smith, 1793

Woodwardia sp. indet. cf. virginica (Linnaeus)

Smith, 1793

Figure 4.3-4

Description. Two specimens of incomplete, sterile, pinnatifid pinnae comparable to Woodwardia cf. virginica have been recovered. Fronds were at least $5.3 \mathrm{~cm}$ long $\times 2.3 \mathrm{~cm}$ wide and $6.0 \mathrm{~cm}$ long $x$ $1.3 \mathrm{~cm}$ wide. The largest pinnule on the first frond is $1.3 \mathrm{~cm} \times 0.4 \mathrm{~cm}$, and the largest pinnule lobe visible on the second frond is $1.0 \mathrm{~cm} \times 0.2 \mathrm{~cm}$. The pinnule lobes become smaller distally (Figure 4.3). On either side of the pinnule midvein, a secondary 


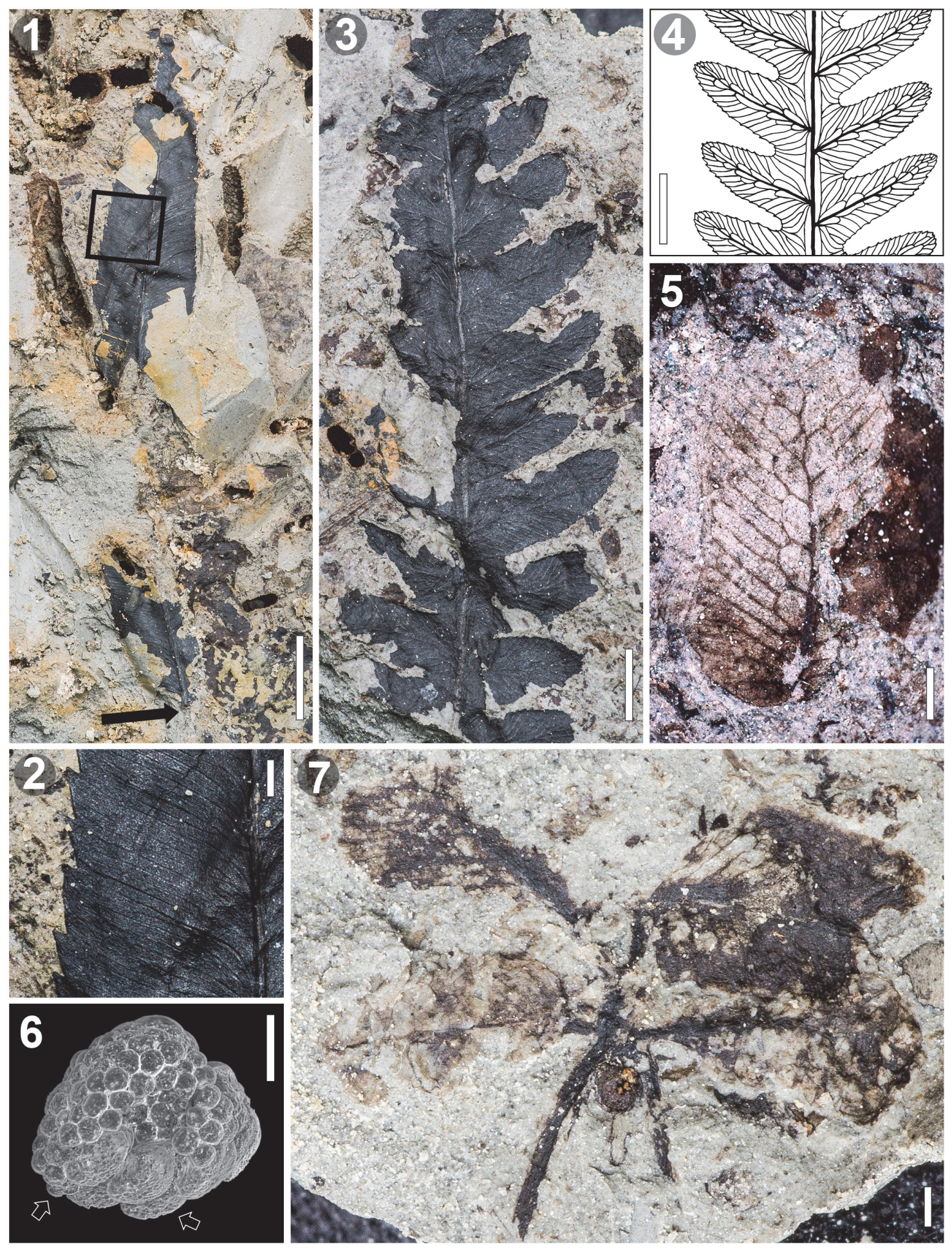

FIGURE 4. Representative ferns from families Osmundaceae, Blechnaceae, and Salviniaceae. 1, Osmunda sp. indet. cf. spectabilis (MMNS PB-82) with arrow indicating partial petiolule, scale bar equals $1 \mathrm{~cm}$. 2, Close-up of rectangle indicated in Figure 4.1 showing fairly parallel secondary veins that branch occasionally, scale bar equals $1 \mathrm{~mm}$. 3, Woodwardia sp. indet. cf. virginica frond (MMNS PB-83), scale bar equals $5 \mathrm{~mm}$. 4, Reconstruction of fossil Woodwardia venation (from MMNS PB-83), scale bar equals $5 \mathrm{~mm}$. 5, Salvinia sp. leaf showing venation (MMNS PB-84), scale bar equals $1 \mathrm{~mm}$. 6, Salvinia sp. SEM of partial sporocarp contents showing microsporangia (left arrow) and megasporangia (right arrow) (MMNS PB-85), scale bar equals $0.5 \mathrm{~mm}$. 7, Salvinia sp. (MMNS PB-86), entire plant with attached sporocarp (with typical yellow-orange coloration), scale bar equals $1 \mathrm{~mm}$. 
vein connects consecutive pinnule lobes. The secondary veins form areoles that parallel both sides of the pinnule midvein. Except for the pinnule lobe midvein, veins within the lobes appear to be of the same gauge. Exmedial veins reach the margin unbranched or fork once before terminating at the margin. Minute teeth occur on the pinnule margin (Figure 4.3-4).

Remarks. Fossils of Woodwardia (and Woodwardites, a name sometimes used for fossil representatives) are common in Cenozoic deposits in Europe, North America, and Asia (Smith, 1938; Collinson, 2001; Pigg et al., 2006). Woodwardia virginica has been definitively identified from the Miocene Yakima Canyon locality in Washington based on excellent reproductive and vegetative specimens (Pigg and Rothwell, 2001). Although fragmentary, the fronds from the Hattiesburg Formation are also very similar to those of $W$. virginica. Common features include the overall morphology, and distinctive venation features like the areoles paralleling the pinnule midvein and the basal secondary vein connecting the pinnules. Nevertheless, we employ the "cf." designation pending the discovery of more complete material. The current distribution of $W$. virginica in North America forms a semi-circular pattern along the southern borders of the Great Lakes (except Lake Superior), running along the Atlantic Coastal Plain (from southern New Brunswick, Canada to the Florida peninsula), and then southwestward along the Gulf of Mexico Coastal Plain to East Texas (Cranfill, 1993+). This is the first suggested occurrence of the genus and species in the fossil record from within its current range.

\section{Family SALVINIACEAE Martinov, 1820 Genus SALVINIA Séguier, 1754 \\ Salvinia sp. \\ Figure 4.5-7}

Description. Two specimens of nearly complete plants, including two sets of paired sterile leaves, connected filamentous leaves, and attached sporocarps have been found (Figure 4.7). Numerous floating leaves (often still characteristically paired on a rhizome fragment), several submerged filamentous leaves with attached sporocarps with characteristic elongate trichomes, and numerous unattached sporocarps have also been recovered. The floating leaves are obovate or oblong, measuring 8-10 x 6-8 mm, with round or slightly emarginate apices and round or slightly cordate bases (Figure 4.5). The mid-vein does not run an entire course to the apex but branches into looping veinlets. Areoles are present on both sides of the mid- vein for its entire course. Evenly spaced veinlets arise from these areoles and diverge at approximately $45^{\circ}$, then form long loops that further divide into smaller loops near the margin. Evenly spaced trichome bases are visible, but the typical "eggbeater" trichomes are no longer attached. Also, many of the leaves probably represent the abaxial surface which lacks the trichomes. Filamentous leaves branch into hair-like segments. Internal components of the sporocarps are often orange in color and often contain both megasporangia and microsporangia (Figure 4.6-7).

Remarks. These fossils occur frequently with other aquatic plants such as Lemna and Cyperus described below. They appear most similar in size and overall morphology to Salvinia minima, but more study is required to acquire a more complete set of comparative features. Of particular interest is the finding that many of the fossil sporocarps from the Hattiesburg locality contain both megasporangia and microsporangia (mixed) (Figure 4.6). Salvinia is widely considered to have sporocarps containing only one of the sporangium types. However, Bierhorst (1971) noted that there is a tendency for some mixed development in the modern forms.

There has been some debate about whether extant Salvinia is native to North America. Although it has been treated as native in several floras, the earliest well-documented collection was made from populations in Florida in the 1930s, and its expansion from there has been well documented (Jacono et al., 2001). Nearly complete plants lacking sporocarps were described from the Eocene of Tennessee (Berry, 1925). This, along with the report here, indicates that Salvinia was a natural component of the southeastern flora at least from the Eocene to the middle Miocene. Globally, spore records of Salvinia are common in the fossil record, but vegetative remains are known from the Upper Cretaceous of Mexico, the Cretaceous/Paleogene of India, the Eocene of France, United States, and China, and the Miocene of Poland and Bohemia/Czech Republic (Collinson, 1991, 1996, 2001; Collinson et al., 2001; Wang et al., 2014).

Subclass PINIDAE Cronquist, Takht. and Zimmerm., 1966

Order CUPRESSALES Bromhead 1838

Family CUPRESSACEAE Richard ex Bartling, 1830

Genus TAXODIUM (Linnaeus) Richard, 1810

Taxodium sp.

Figure 5.1-2 
Description. Leaves are about 5-18 x 1-1.5 mm, alternately attached on deciduous branchlets (Figure 5.1). Leaf apices are acute. Leaves have a single vascular strand. Stomata are transversely oriented to the primary vein (Figure 5.2).

Remarks. Leaf fossils are common at the site, but intact cuticle was very difficult to recover. No cones or cone scales have been found, so we refrain from a species level identification. Taxodium was previously reported from the Tallahala Creek Locality of the Hattiesburg Formation, although no figures were provided or mention made of what plant organs were examined (Brown, 1944). Acute leaf apices and perpendicularly orientated stomata separate Taxodium from other cupressaceous genera (Farjon, 2005; Mai et al., 2013) and are present in the Bouie River material. Taxodium was widespread in Eurasia and North America during the Paleogene and Neogene (Knobloch and Mai, 1986; Aulenback and LePage, 1998; Kunzmann et al., 2009). The distribution of the genus is relictual, currently found only in the southeastern United States ( $T$. distichum and $T$. ascendens) and Mexico (T. mucronatum) (Kunzmann et al., 2009). In the southeastern Neogene fossil record, it is a common component of the Miocene Brandywine flora of Maryland and the Pliocene Citronelle Formation flora in south Alabama (Stults et al., 2011).

\section{Order LAURALES Perleb, 1826 \\ Family LAURACEAE de Jussieu, 1789 \\ Gen. et sp. indet. cf. Persea Miller, 1754}

Figure 5.3-7

Description. Two entire-margined lauraceous leaves with possible affinities to Persea were recovered. One is obovate $(7.8 \mathrm{~cm} \times 4.0 \mathrm{~cm})$ (Figure 5.3) and one elliptical $(8.6 \mathrm{~cm} \times 3.4 \mathrm{~cm})$. Bases are decurrent in both specimens. The apex is incomplete in the obovate specimen, but obtuse and appears to have been acuminate. The apex in the elliptical specimen is acute, acuminate. Primary venation is pinnate (Figure 5.4, 6). Secondary venation is difficult to categorize-somewhat brochidodromous to somewhat eucamptodromous. Secondary veins are non-arcuate, irregularly spaced, with angles diverging from the primary vein fairly consistently at about $45^{\circ}$. Intersecondaries are few, but when visible appear more obvious toward the apex. The marginal vein is substantial and categorized as a secondary vein. Tertiary venation is irregular reticulate. Fourth and fifth order veins in the obovate specimen are regular reticulate (Figure 5.4). Stomata are paracytic (Figure 5.5). Spherical oil bodies are visible in the mesophyll of the obovate specimen under light microscopy (Figure 5.7) and under epifluorescence in the elliptical specimen.

Remarks. The features of these leaves clearly indicate affinity with the Lauraceae, especially the size and distribution of the oil bodies in the mesophyll (Watson and Dallwitz, 1992+). This feature is comparable to many extant species including Lindera benzoin, a common species of sandy riparian habitats of the southeastern United States. The paracytic stomatal complexes are also common for taxa within the Lauraceae (Watson and Dallwitz, 1992+; Christophel et al., 1996) (Figure 5.5). The regular reticulate fourth and fifth order venation is common in many taxa including Persea, as are the strong marginal secondary veins and apparent coriaceous texture. Overall, these fossils appear most similar to Persea, but until more information is available, we use the "cf." designation.

Currently, there are about 50 genera and 2500-3000 species of Lauraceae, several genera of which (e.g., Lindera, Litsea, Persea, and Sassafras) show the classic disjunction between tropical/ subtropical areas in southeastern Asia and North America (Chanderbali et al., 2001). However, Ocotea is the most speciose lauraceous genus in the neotropics (Chanderbali et al., 2001). Fossils of the family appear by the mid-Cretaceous, but the Asian/American disjunction of the Perseae-Laureae clade ensued with late Eocene cooling (Wolfe, 1975; Tiffney, 1985; Zheng, 1983; Drinnan et al., 1990; Eklund and Kvaček, 1998; Chanderbali et al., 2001). Lindera, Persea, and Sassafras have been reported from the Upper Pliocene of South Alabama (Stults and Axsmith, 2015).

Order DIPSICALES Juss. ex Bercht. and J. Presl, 1820

Family ADOXACEAE Meyer, 1839

Genus SAMBUCUS Linnaeus, 1753

Sambucus sp.

Figure 5.8-10

Description. Leaflets are mostly ovate, although a few are elliptic. Laminar width is generally symmetrical, but slight asymmetry occurs in several leaflets at the petiolule insertion point (a common feature of the leaflets of extant Sambucus) (Figure 5.8). Most leaflets are incomplete; however, width ranges of the original leaflets are about 2.0-4.3 $\mathrm{cm}$. The smallest complete leaflet length is $4.3 \mathrm{~cm}$, and larger specimens were greater than $7.2 \mathrm{~cm}$ long. Margins are unlobed and serrate (Figure 5.89 ). Leaflet bases are acute and convex. When a petiolule portion is present, the base appears to be decurrent. However, most of the fossil leaflets appear to have been sessile, recognizable by the 

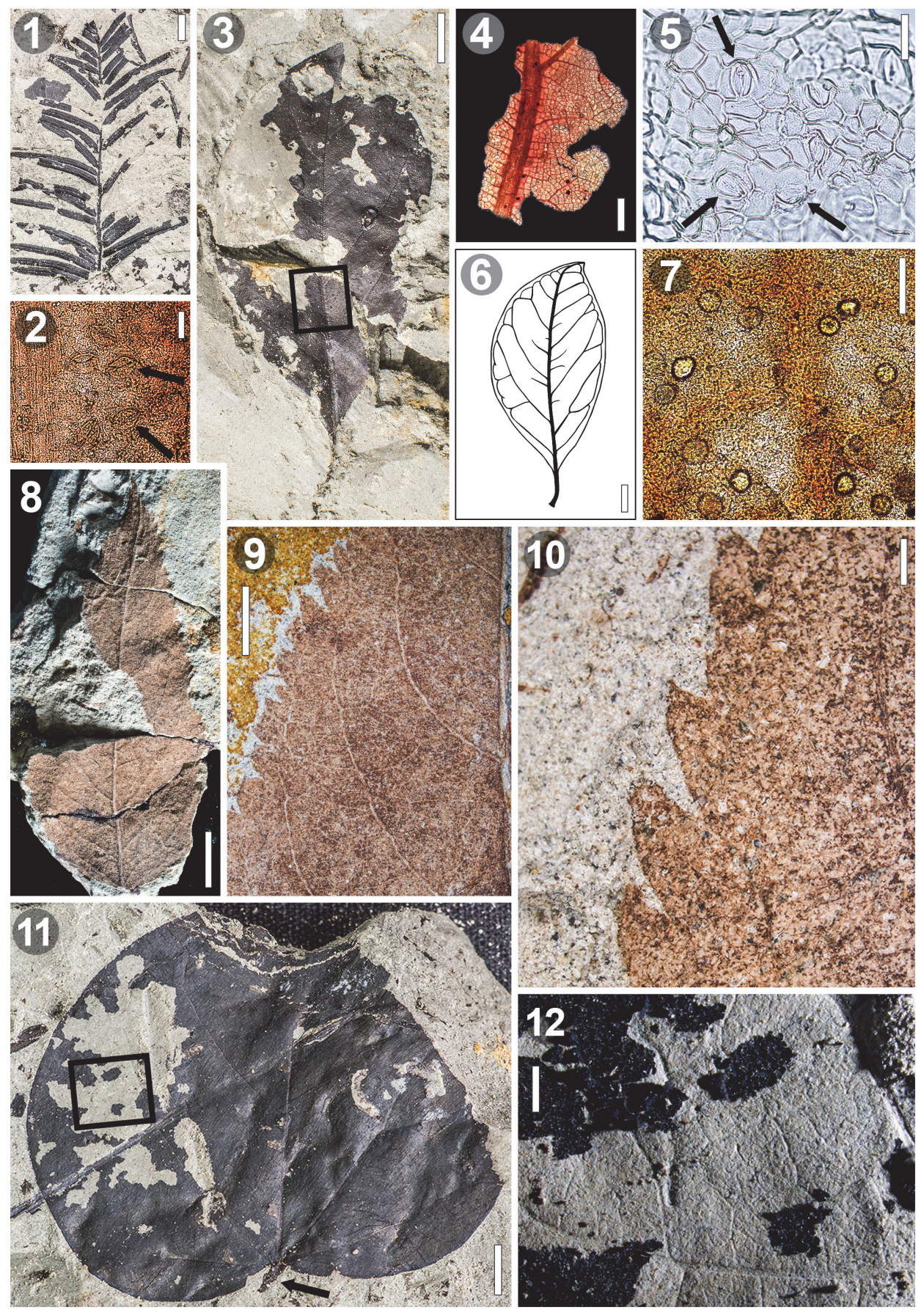

FIGURE 5. Representatives of gymnosperm family Cupressaceae and angiosperm families Lauraceae, Adoxaceae, and Fabaceae. 1, Taxodium sp. branchlet (MMNS PB-87.1), scale bar equals $5 \mathrm{~mm}$. 2, Taxodium sp. lower cuticle showing stomata (MMNS PB-87.2), scale bar equals $0.05 \mathrm{~mm}$. 3, Lauraceae gen. et sp. indet. cf. Persea sp. nearly complete leaf (MMNS PB-88.1), scale bar equals $1 \mathrm{~cm} .4$, Partial lamina extracted and cleared (MMNS PB-88.2) from the same fossil in Figure 5.3 with extraction area indicated by rectangle, scale bar equals $2 \mathrm{~mm}$. 5, Cuticle from the same fossil as in Figure 5.3 showing paracytic stomatal complexes indicated by arrows (MMNS PB-88.3), scale bar equals $0.05 \mathrm{~mm}$. 6, Reconstruction of venation features of the fossil in Figure 5.3. 7, Oil bodies from the same fossil as in Figure 5.3 (MMNS PB-88.4), scale bar equals $2 \mathrm{~mm}$. 8, Sambucus sp. nearly complete leaflet (MMNS PB-89), scale bar $1 \mathrm{~cm}$. 9, Sambucus sp. partial lamina, venation close-up (MMNS PB-90), scale bar equals $5 \mathrm{~mm}$. 10, Sambucus sp. partial lamina, close-up of marginal teeth (MMNS PB-91), scale bar equals $1 \mathrm{~mm}$. 11, Cercis sp. partial leaf with pulvinus indicated with an arrow (MMNS PB-92), scale bar equals $5 \mathrm{~mm}$. 12, Close-up rectangle in Figure 5.11 showing impressions of higher order venation, scale bar equals $1 \mathrm{~mm}$. 
asymmetry at the basal end and lack of a petiolule. Apices are acute and straight to acuminate. Primary vein framework of the leaflets is pinnate. Secondary veins are mostly cladodromous, excurrent, irregularly spaced with inconsistent angles, and conspicuously arcuate. Intersecondaries are rare, and if present, observable only at the basal end. Third order veins are mixed percurrent with inconsistent angles. Fourth order venation is also mixed percurrent. Fifth order veins are sometimes observable, but difficult to characterize. The leaflet margins have one order of relatively large, serrated teeth, although an extraneous tooth is sometimes evident (a feature common in extant Sambucus). Teeth are regularly spaced with angular sinuses, straight to concave on the distal side and convex on the proximal side. Tooth apices are simple (more like that of $S$. racemosa rather than $S$. canadensis, which displays a setaceous tooth apex) (Figure 5.10). The number of teeth/cm is also more similar to $S$. racemosa.

Remarks. Twenty leaflets are assigned to Sambucus sp. making it the most common eudicot taxon in the collection. The genus Sambucus includes about 25 species of shrubs, small trees, and herbs distributed mainly in temperate and subtropical regions of the Northern Hemisphere, in both wet and dry soils (Little, 1977; Eriksson and Donoghue, 1997). Seven species occur in North America, three occurring in eastern portions of the continent. Sambucus canadensis (considered a subspecies of $S$. nigra by some) occurs mainly in the eastern United States and some areas west of the Mississippi River. Sambucus racemosa is widespread in North America but in the southeast is native only in Georgia, North Carolina, Virginia, Tennessee, Kentucky, and Arkansas. Sambucus ebulus inhabits only the northeastern portion of North America (Little, 1977; USDA GRIN online database, www.arsgrin.gov).

The fossil record of Sambucus is based mostly on endocarps found in the Paleocene through Holocene of Europe, Asia, and North America (see references in table 4 of Huang et al., 2012). Leaves/leaflets have been less reliably recorded, but a North American record of a compound leaf and additional leaflets has been verified for the Eocene of Florissant, Colorado (MacGinitie, 1953; Manchester, 2001). Leaflets of Sambucus are easily disassociated from the overall compound leaf, as noted in natural populations of $S$. canadensis in southern Alabama (based mainly on personal observations of an extensive population along the floodplain of Muddy Creek in the Muddy
Creek Management Area of southern Mobile County, Alabama). These fossils are somewhat similar to those described as Ulmus floridana by Berry (1916a), which also occur at the Alum Bluff locality in Liberty County, Florida (Corbett, 2004). However, the leaves described here as Sambucus have prominent simple teeth. Additionally, the secondary veins are arched and the cladodromous organization appears variable and disorganized compared to secondary venation patterns typically seen in Ulmus or Prunus. Furthermore, these leaflets are different from Prunus leaves in lacking glands on the teeth or leaf base.

Order FABALES Bromhead, 1838

Family FABACEAE Lindley, 1836

Genus CERCIS Linnaeus, 1753

Cercis sp.

Figure 5.11-12

Description. One compression/impression fossil leaf is broadly ovate measuring $4.6 \mathrm{~cm}$ wide, but if assuming symmetry on both sides of mid-vein, the original leaf would have been about $5.1 \mathrm{~cm}$ wide (Figure 5.11). The leaf is un-lobed with an entire margin. The base is symmetrical, cordate. Venation is actinodromous consisting of five primary basal veins. Simple agrophic veins are exmedial to the outermost primary veins. One agrophic complex originates with a basal vein; therefore, six total basal veins are observable. Assuming symmetry, a seventh basal vein was probably present on the opposite agrophic complex. Major secondary venation is camptododromous to brochidodromous. Secondary interior veins are present between the major primary veins. Third order veins are mixed percurrent to irregular reticulate. Fourth and fifth order venation patterns are irregular reticulate (Figure 5.12). A $1.5 \mathrm{~mm}$ thickening of the petiole near the base is interpreted as a pulvinus (Figure 5.11).

Remarks. Observations of herbarium specimens of the four extant North American species of Cercis (C. canadensis, C. mexicana, C. reniformis, $C$. occidentalis) primarily show seven primary veins rather than five (as we describe for the Hattiesburg leaf fossil). However, examination of $C$. canadensis specimens in the USAM and USMS herbaria demonstrate that five to nine basal veins can be recognized, the determination of which to consider primary veins vs. non-primary basal veins possibly being dependent upon the size of the specimen. There are modern species in eastern Asia that appear predominately 5-veined (e.g., C. racemosa, Chen et al., 2010). The well-described fossil North American Eocene species C. parvifolia (Florissant of Colorado) also usually shows five primaries. 
Apparently, this leaf venation character does not allow differentiation among the species of Cercis (Jia and Manchester, 2014). Agrophic veins appear in some herbarium specimens of $C$. canadensis but not in others. The only record of Cercis from eastern North America is identified as the extant species C. canadensis from the Pleistocene of North Carolina (Berry, 1926). The Bouie River site Cercis is significant in that it represents the oldest leaf fossil of the genus in eastern North America.

Order FAGALES Engl., 1892

Family FAGACEAE Dumortier, 1829

Genus QUERCUS Linnaeus, 1753

Section Lobatae Loudon, 1830

Quercus sp. 1

Figure 6.1

Description. Three Quercus section Lobatae compression/impression leaf fossils are identified. Lobes are shallow. Bristle tips approximately $2 \mathrm{~mm}$ long occur on the lobe apices. Primary venation is pinnate. Some secondaries end in the lobe bristle tip, other secondaries are brochidodromous. Intersecondaries are present. Third order, fourth order, and fifth order veins are irregular reticulate. A fimbrial vein is present (Figure 6.1).

Section Quercus Hickel and Camus in Camus, 1938

Quercus sp. 2

Figure 6.2-3

Description. Leaves are obovate, ovate, or elliptical. Most have shallow lobes, but some have more definitive lobes. One mostly complete specimen is $6.6 \mathrm{~cm}$ long $\times 2.4 \mathrm{~cm}$ wide. Primary venation is pinnate. Some secondary veins terminate at the margin of lobe apex, other secondaries are brochidodromous or cladodromous. Secondary veins diverge at approximately $45^{\circ}$. Intersecondaries are present. Third and fourth order venation is irregular, reticulate. The petiole of one the attached leaves is $1 \mathrm{~cm}$ long. Several specimens have rounded lobes (Figure 6.3), while a few have pointed lobes with no evidence of bristles (Figure 6.2), so it appears that there may be at least two species of section Quercus in the collection.

Remarks. Six Quercus section Quercus leaf fossils are identified. Four are compression fossils (Figure 6.2 ), including one slab with two young leaves still attached to the stem (Figure 6.3). Two are impressions, one with a counterpart. Comparison of these leaves with Quercus species from the USAM and USMS herbaria suggest the possibility that oaks related to Quercus alba (those with rounded lobes) and Quercus lyrata (those with pointed lobes, but no bristles) may be a part of this flora, but this is uncertain based on the available material. More leaf specimens and some reproductive structures will be needed for confident identification.

Quercus is widely distributed throughout the Northern Hemisphere, with its greatest diversity in the southeastern United States, the highlands of Mexico, montane subtropical Eurasia, and East Asia (Nixon, 1993, 1997). Presence or absence of lobes, in conjunction with the presence or absence of bristles are leaf characters useful in subgenus determination (Daghlian and Crepet, 1983). Quercus section Lobatae species have stiff bristles at the end of lobes/teeth, or if entire, at the end of the leaf apex (Daghlian and Crepet, 1983). Quercus section Quercus species (if lobed) usually have lobes without bristles, although the ends of the lobes may be pointed and mucronate (Nixon and Muller, 1997), as is the case with Q. lyrata. Quercus section Protobalanus usually has spiny teeth without bristles and is found mainly in the western U.S. (Manos, 1997). Quercus fruit and leaf fossils have been identified in North America from the middle Eocene of the West, while Quercus leaf and fruit records from the eastern portion of the continent occur in the late Miocene Brandywine flora and the late Pliocene Citronelle Formation flora (MacGinitie, 1941; Wolfe, 1973; Crepet and Daghlian, 1980; McCartan et al., 1990; Manchester, 1994; Stults, 2003). Records of section Lobatae fossil leaves have been recovered from the Oligocene of eastern Texas and from the Citronelle Formation of Alabama (Daghlian and Crepet, 1983; Stults, 2003). The Hattiesburg Formation fossils help to fill in a partial gap in the Miocene North American record of Quercus for both sections Lobatae and Quercus.

Family JUGLANDACEAE de Candolle in Perleb, 1818

Genus JUGLANS Linnaeus, 1753

Section RHYSOCARYON Dode, 1909a, 1909b Juglans $\mathrm{sp}$.

Figure 6.4

Description. Globose nut $3.1 \mathrm{~cm}$ long x $2.1 \mathrm{~cm}$ wide, but wider equatorially than axially. The nutshell is longitudinally grooved, and the surfaces between the grooves are slightly rugose to smooth (Figure 6.4 top). The nutshell is thick, measuring 3 $\mathrm{mm}$ at the equatorial section. The two-lobed kernel is preserved and visible within the nutshell (Figure 6.4 bottom).

Remarks. Juglans is divided into four sections by Manning (1978). The most recent molecular phylogeny by Aradhya et al. (2005) indicates that 

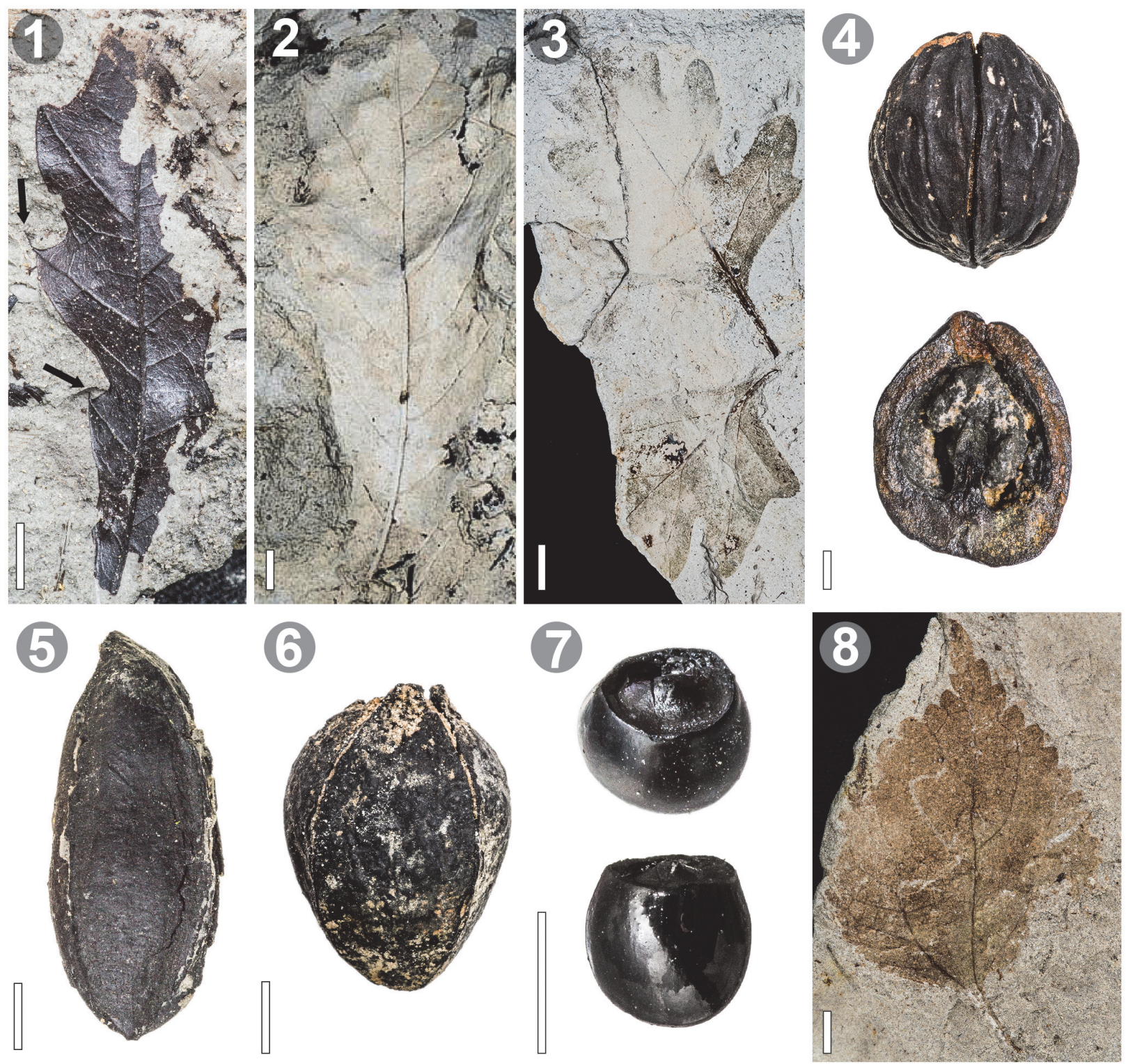

FIGURE 6. Representatives of angiosperm families Fagaceae, Juglandaceae, Lardizabalaceae, and Moraceae. 1, Quercus section Lobatae leaf (MMNS PB-93), scale bar equals $5 \mathrm{~mm}$. 2, Quercus section Quercus leaf (MMNS PB94), scale bar equals $5 \mathrm{~mm}$. 3, Two Quercus section Quercus leaves attached to stem (MMNS PB-95), scale bar equals $5 \mathrm{~mm}$. 4, Juglans sp. complete nut with preserved kernel visible inside (MMNS PB-96), scale bar equals $5 \mathrm{~mm}$. 5, Carya sp. 1 complete nut (MMNS PB-98), scale bar equals $5 \mathrm{~mm}$. 6, Carya sp. 2 complete nut (MMNS PB-97), scale bar equals $5 \mathrm{~mm}$. 7, Sargentodoxa sp. complete seed from two angles (MMNS PB-99), scale bar equals $5 \mathrm{~mm}$. 8, Morus sp. nearly complete leaf (MMNS PB-100), scale bar equals $5 \mathrm{~mm}$.

these sections are mostly monophyletic. However, section Trachycaryon, represented by one species (Juglans cinerea), is nested within section Rhysocaryon, which contains all of the New World Juglans. Aradhya et al. (2005) also found little resolution among Rhysocaryon species, even though the clade as a whole was well-supported. Our material shows typical features of section Rhysocaryon, but its fewer grooves and smooth, non-warty between-groove ridges are more like Juglans major or similar species extant in the western U.S. than to the extant eastern species Juglans nigra. There is no evidence for abrasion or long transport, suggesting that this is a real feature and not a taphonomic artifact. There is also evidence for deep ridges in the shell cross-section (Figure 6.4 top). The fossil is also dissimilar in these features to Juglans cinerea, whose distribution is 
mainly east of the Mississippi River, but not reaching the Gulf of Mexico Coastal Plain. The precise relationships of this fossil will be considered in more detail in a forthcoming study. Juglans fruits have occasionally been found in western North American deposits dating back to the Eocene (Manchester, 1994). The fossils described here represent the first fossil record of Juglans fruit from eastern North America.

Genus CARYA Nuttall, 1818

Section APOCARYA de Candolle, 1864

Carya sp. 1 and 2

Figures 6.5-6

Description. Carya sp. 1 fruit is longer and thinner, measuring $2.7 \times 1.1 \mathrm{~cm}$. The husk is four-valvate, but the sutures are more obviously flanged than in Carya sp. 2. The husk is also much thinner at approximately $0.51 \mathrm{~mm}$ thick. Carya sp. 2 fruit is oblong, measuring $2.0 \times 1.5 \mathrm{~cm}$. The husk is fourvalvate, has slightly flanged sutures, and is 1.04 $\mathrm{mm}$ thick. The nutshell shows the quadrangular shape corresponding to the lines of dehiscence of the husk (Manchester, 1987).

Remarks. Fossil evidence suggests Carya evolved in North America at the end of the Cretaceous, approximately $67 \mathrm{Ma}$ (Zhang et al., 2013). Two sections of the genus are recognized. This divergence apparently occurred $22 \mathrm{Ma}$, with one section corresponding to the species in East Asia and the other to those of eastern North America (Zhang et al., 2013). The current center of diversity for Carya is eastern North America (Thompson et al., 1999). However, until recently, the majority of North American Carya megafossils were identified from western localities (as early as the Eocene), where the genus no longer exists (Manchester, 1987, 1999; Zhang et al. 2013). The contemporary center of diversity for Carya is now producing a muchimproved fossil record, with megafossils identified from the late Miocene Brandywine locality (northern Virginia), the Miocene-Pliocene Gray Fossil site (eastern Tennessee), and the Citronelle Formation (southern Alabama) (Berry, 1916b; McCartan et al., 1990; Huang et al. 2014; Stults and Axsmith, 2015). The new Miocene records from the Hattiesburg Formation described here help fill a Miocene gap for the biogeography of Carya. So far, no leaves of Carya have been recovered from the Bouie River site, but pollen is common and will be described in a forthcoming publication.

Order RANUNCULALES Dumortier, 1829

Family LARDIZABALACEAE Brown, 1821

Genus SARGENTODOXA Rehder and Wilson,
1913

Sargentodoxa sp.

Figure 6.7

Description. A single globose seed $6 \mathrm{~mm}$ long with a truncate apex and round base has been found. Diagnostic features include a smooth surface, thick seed coat (up to about $300 \mu \mathrm{m}$ ) (Figure 6.7 top), a prominent hilar rim, and a central micropyle (Figure 6.7 bottom).

Remarks. Sargentodoxa is represented by a single species of vine ( $S$. cuneata) found in parts of China, Laos, and Vietnam. It is recognizable by its distinctively smooth, shiny globose seed coat and prominent apical truncation (Tiffney, 1993). A review of the fossil record of the genus by Manchester et al. (2009) included seeds from the middle Eocene of Oregon, the late Eocene to late Oligocene of northwest Saxony, the early Miocene of Vermont, the middle Miocene of Germany, the uppermost Miocene-Lower Pliocene of Alsace, and the Pliocene of Italy. There is also a brief mention of Sargentodoxa seeds from the latest Mioceneearliest Pliocene Gray Fossil site in northeastern Tennessee (Gong et al., 2010). The Hattiesburg Formation seed expands the fossil record of the genus to the Gulf Coastal Plain of North American during the middle Miocene.

Order ROSALES Bercht. and J. Presl, 1820 Family MORACEAE Gaudichaud-Beaupré, 1835

Genus MORUS Linnaeus, 1753

Morus sp.

Figure 6.8

Description. The largest specimen is $4.5 \mathrm{~cm}$ long $x 4.0 \mathrm{~cm}$ wide with three lobes; a smaller specimen is $4.2 \mathrm{~cm}$ long $\times 3.1 \mathrm{~cm}$ wide and not lobed. Leaf attachment is petiolate, a $0.8 \mathrm{~cm}$ petiole present on the smaller specimen. Leaf margins are toothed. Base angles are obtuse, base shape is asymmetrical in the large specimen, convex in the smaller fossils. Primary venation is palmate with three primary veins. Simple agrophic veins are present. Costal secondary veins are semicraspedodromous. Third order veins are usually straight percurrent or sinuous percurrent, but occasionally alternate percurrent. Fourth and fifth order venation is regular, reticulate. Teeth are regularly spaced, convex distally and proximally, approximately three teeth per centimeter, the principal tooth vein terminating at the non-glandular apex (Figure 6.8).

Remarks. Morus consists of 10-13 species. Four of these species ( $M$. celtidifolia, $M$. insignis, $M$. microphylla, and $M$. rubra) are native to North America, but only $M$. rubra is native to eastern 
North America (Nepal and Ferguson, 2012). Morus celtidifolia and $M$. microphylla are sister taxa to $M$. rubra, all three being sister to the Asian species of Morus (Nepal and Ferguson, 2012). Two previously published records for Morus are from the Alaskan Cenozoic and the New Jersey Pleistocene (Hollick, 1892; Keller et al., 1961).

Glen Brown (1944) sent specimens of Hattiesburg Formation plant fossils to paleobotanist Roland Brown who identified some as "Morus or Celtis." Assuming our fossils are similar, we suggest that our material represents Morus rather than Celtis based on the following observations. Some Celtis leaves have similar venation to Morus (up to fourth and fifth orders), but Celtis leaves are more elongate with less regularly spaced teeth. To support this quantitatively, we performed a small study of $L: W$ ratios between the two genera based on specimens in the USAM herbarium. Using 21 specimens for Celtis (which included C. laevigata, $C$. occidentalis, and C. tenuifolia), one mature leaf per sheet was selected that exhibited the least difference between length and width measures (i.e., least L:W ratio). Twenty specimens of Morus (including $M$. alba, M. nigra, and $M$. rubra) that showed the largest difference between length and width (e.g., largest L:W ratio) were measured. The mean L:W ratio for Celtis using specimens with the least $\mathrm{L}: \mathrm{W}$ ratios was 2.2:1, whereas the mean $\mathrm{L}: \mathrm{W}$ ratio for Morus using specimens with the largest $\mathrm{L}: \mathrm{W}$ ratios for Morus was $1.6: 1$, showing a $40 \%$ difference even when using specimens biased to show as much overlap as possible. Another noteworthy difference between Celtis and Morus leaves is the lobation. Morus is typically lobed, whereas Celtis leaves are rarely lobed (Godfrey, 1988). The broad teeth that are convex both proximally and distally on the fossils are also more characteristic of Morus than Celtis. The circumscription of the family Moraceae currently includes 37 genera (Datwyler and Weiblen, 2004). Of these, only leaves of Broussonetia, which is currently native to Southeast Asia, has leaves that are similar to Morus, but with very hairy abaxial surfaces. However, unless reproductive material becomes available, Morus is most likely as the genus is present today in the same region.

Order PROTEALES Dumort., 1829

Family PLATANACEAE Lestiboudois, 1826

Genus PLATANUS Linnaeus, 1753 Platanus sp.

Figure 7.1-3

Description. Six Platanus compression leaf fossils (two complete and four partial specimens), one partial fruiting head, and three foliose stipules are identified. The largest leaf specimen is $20.0 \mathrm{~cm}$ long $\times 20.5 \mathrm{~cm}$ wide (including a $2.6 \mathrm{~cm}$ petiole). Unfortunately, in this largest specimen, a small portion near the base is overlain by another leaf fossil masking the complete primary venation. A mostly complete smaller specimen $12.0 \mathrm{~cm}$ long $\times 13.0 \mathrm{~cm}$ wide, along with a fragmentary specimen (with a $1.7 \mathrm{~cm}$ petiole) provide evidence for the palinactinodromous primary venation typical of the genus (Figure 7.1). Margins are serrate/dentate with at least five lobes visible on the largest specimen; three large lobes and two shallow lobes are identifiable on the smaller complete specimen. Length/ width ratios are approximately 1:1. Leaf bases are either obtuse/rounded or lobate, apices are acute. Compound agrophic veins are evident. Costal second order veins are craspedodromous, third order veins between costal secondaries are a percurrent mixture (straight, sinuous, alternate percurrent). Fourth order veins are irregular reticulate and more difficult to pinpoint than the fine meshwork of the fifth order veins, which are regular reticulate. Margins have simple teeth of one order, even though variable in size (Ellis et al., 2009). Rarely a small, secondary tooth is present. Teeth occur 1-3 per $\mathrm{cm}$, smaller teeth are regularly spaced, while larger teeth are more often irregularly spaced. Sinuses between the teeth are rounded. Teeth are concave/ straight both distally and proximally. Two mostly complete stipules with evidence of five pointed lobes and a few teeth between lobes, and one incomplete stipule showing three lobes and no teeth are recognized (Figure 7.2). Of the more complete stipule specimens, one measures $3.5 \mathrm{~cm}$ at its widest while the other measures $2.7 \mathrm{~cm}$ at its widest point. The larger stipule base displays the broad attachment that would have encircled the petiole. The partial fruiting head measures $1.9 \mathrm{~cm}$; eight achenes are visible, and one achene shows a persistent style that is about $9 \mathrm{~mm}$ long $\times 1 \mathrm{~mm}$ wide. Hairs of the pappus are attached to the achene bases (Figure 7.3)

Remarks. The fossil record of Platanus fruits and leaves begins in the Paleocene of eastern Russia (Maslova, 1996; Manchester, 1999). Miocene records occur in western North America in the Clarkia and Succor Creek floras (Smiley and Rember, 1985; Fields, 1996). Probable fossils of $P$. occidentalis have been reported from the late Miocene Brandywine flora of Maryland, and definite P. occidentalis fossils have been identified from the Pliocene Citronelle Formation (McCartan et al., 1990, Stults and Axsmith, 2015). Of the three (or four) 


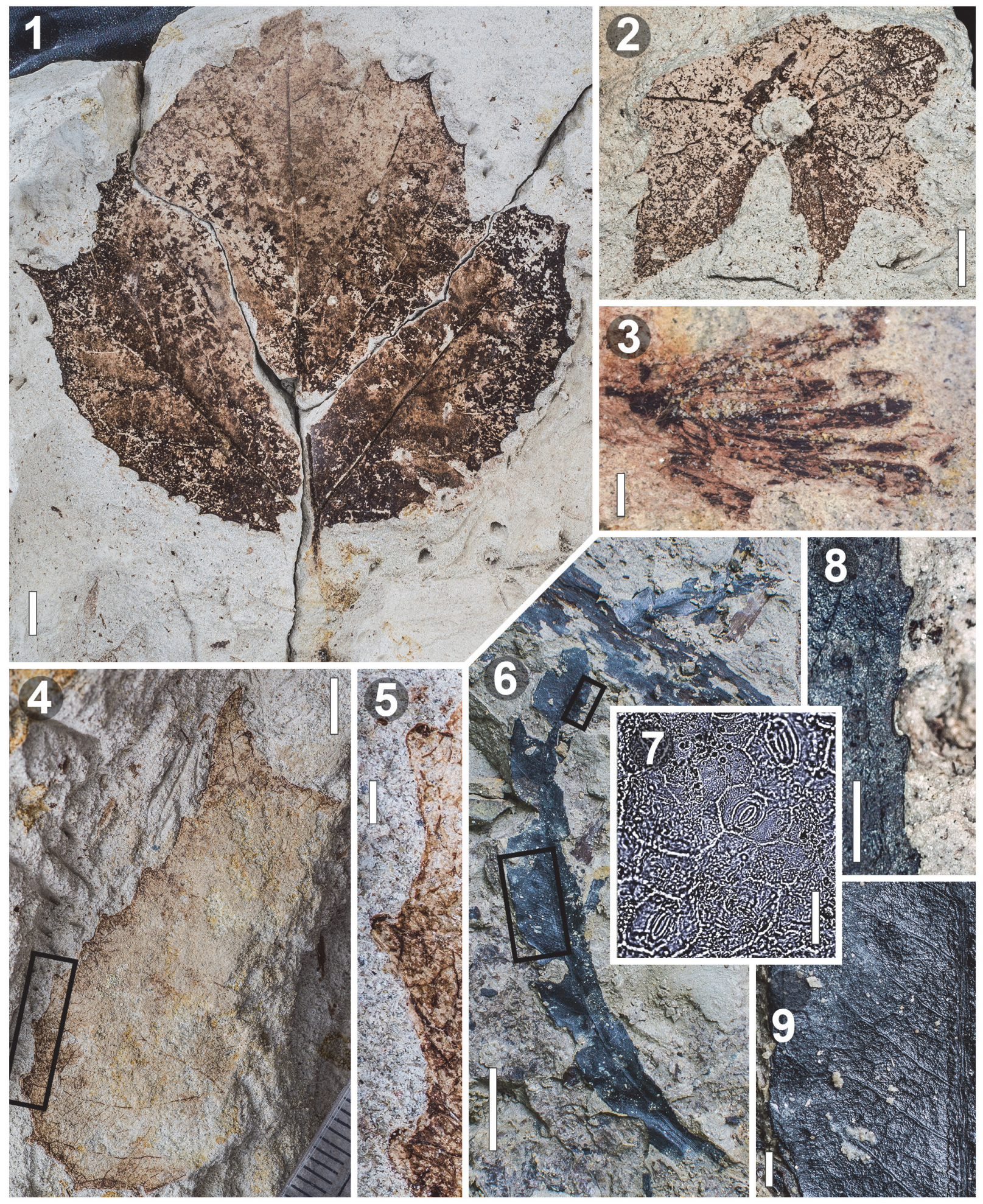

FIGURE 7. Representatives of angiosperm families Platanaceae and Salicaceae. 1, Platanus sp. nearly complete leaf (MMNS PB-101), scale bar equals $1 \mathrm{~cm}$. 2, Platanus sp. stipule (MMNS PB-102), scale bar equals $5 \mathrm{~mm} .3$, Platanus sp. fruit section (MMNS PB-103), scale bar equals $1 \mathrm{~mm}$. 4, Populus sp. indet. cf. deltoides partial leaf (MMNS PB104), scale bar equals $5 \mathrm{~mm}$. 5, Close-up of rectangle in Figure 7.4 showing teeth, scale bar equals $1 \mathrm{~mm} .6$, Salix sp. partial lamina (MMNS PB-105.1), scale bar equals $1 \mathrm{~cm}$. 7, Lower cuticle fragment of the same fossil (MMNS PB105.2), scale bar equals $0.02 \mathrm{~mm}$. 8, Close-up of Figure 7.6 (smaller) rectangle showing teeth, scale bar equals 1 $\mathrm{mm}$. 9, Close-up of Figure 7.6 (larger) rectangle showing venation, scale bar equals $1 \mathrm{~mm}$. 
species of Platanus currently found in North America, $P$. racemosa and $P$. wrightii (or possibly $P$. racemosa var. wrightii) occur in western regions, while $P$. occidentalis has a wide distribution along streams and rivers in eastern North America (Godfrey, 1988). The Mississippi fossils described here are very similar to $P$. occidentalis and occur within its current range; however, we refrain from a species level identification at this time based on their age and the low levels of morphological differentiation of most modern forms.

Order MALPIGHIALES Juss. ex Bercht. and J. Presl, 1820

Family SALICACEAE Mirbel, 1815

Genus POPULUS Linnaeus, 1753

Populus sp. indet. cf. deltoides Bartram ex Marshall, 1785

Figure 7.4-5

Description. The smaller leaves range from 2.6$4.1 \mathrm{~cm}$. long $\times 3.4-3.6 \mathrm{~cm}$. wide. One of the larger leaves is $6.5 \mathrm{~cm}$ long. The other larger leaf had an estimated width of $6.8 \mathrm{~cm}$. The overall shape is ovate, and the margins are toothed. Four leaves have a truncate base, while one appears to be slightly cordate. Apices are acuminate, one extending into an elongated tip (Figure 7.4). Primary venation is pinnate. Compound agrophic veins are visible in two of the better-preserved smaller leaves. Second order venation is semi-craspedodromous, third order veins are mixed percurrent, fourth and fifth order venation is irregular reticulate. One order of regularly-spaced teeth is present, approximately 3-5 per $\mathrm{cm}$, with distal flanks concave, straight, or convex and proximal flanks convex or straight. Several teeth are retroflexed. Salicoid teeth are visible on several specimens (Hickey and Wolfe, 1975; Wilkinson, 2007). Tooth sinuses are angular or rounded (Figure 7.5).

Remarks. The fossil record of Populus begins in North America in the late Paleocene and the genus spreads widely during the Eocene (Eckenwalder, 1980; Manchester et al., 2006). Populus species currently native to wet lowlands in the southeastern United States are $P$. deltoides, with its very wide, almost continent-wide distribution, and $P$. heterophylla, with a spottier distribution from parts of the United States east of the Mississippi River (Godfrey, 1988). Populus deltoides has a Pliocene fossil record from the Citronelle Formation of southern Alabama (Stults and Axsmith, 2011). Populus heterophylla leaves are distinct from those of $P$. deltoides based upon their lack of acuminate apices (Godfrey, 1988).
Three small leaves, two mostly complete and one partial, and two larger partial leaves were recovered from the Hattiesburg Formation. The petiole is evident on two of the small leaves. The specimens have acuminate apices, suggesting that $P$. deltoides or a possible precursor species existed along the Gulf of Mexico Coast by at least the middle Miocene.

\section{Genus SALIX Linnaeus, 1753 Salix sp. \\ Figure 7.6-9}

Description. One almost complete linear leaf measures $8.0 \mathrm{~cm}$ long $\times 0.8 \mathrm{~cm}$ wide (the original L:W ratio would have been $>10: 1$ (Figure 7.6). Neither base nor apex are present. Although typified as linear (Ellis et al., 2009), the preserved basal portion of the leaf is wider than the apical portion. The abaxial cuticle obtained is fragmentary and not well preserved but contains paracytic stomata about 20 $\mu \mathrm{m}$ long and regular epidermal cells with straight to somewhat curved cell walls (Figure 7.7). These are common epidermal features among extant Salix species (Chen et al., 2008). One order of small teeth $(6-7$ per $\mathrm{cm})$ is present (Figure 7.8). Tooth shapes are distally straight or concave and proximally straight or convex. Opaque tissue possibly representing a salicoid tooth is present on the apex. Between-teeth sinuses are angular or rounded. First order venation is pinnate. Second order venation is semicraspedodromous and some secondaries are arcuate. Third order venation is irregular reticulate (Figure 7.9).

Remarks. Teeth in Salix are variable, with some species maintaining a large spheroidal gland at the tooth apex while others lack a gland or the gland withers or abscises with age (Reinke, 1876; Weber, 1978; Wilkinson, 2007; Beuchler, 2014). We also note that herbarium samples of Salix may not have completely intact tooth apices potentially due to degradation during storage. We suggest that prior to fossilization or to the degrading processes before/during fossilization the tooth apices on the original leaf were probably spherulate. Of the approximately 450 species of Salix worldwide, 113 species occur in North America. Those found in the southeastern United States including southern Mississippi (Kartesz, 2015), Alabama, Florida, and Georgia (Godfrey, 1988) are S. caroliniana, S. eriocephala, S. floridana, S. humilis, S. interior, and $S$. nigra. Based on leaf dimensions, the specimen from the Hattiesburg Formation is most similar to extant S. caroliniana, S. eriocephala, S. interior, or $S$. nigra. Reproductive and vegetative fossils of Salix have been found in Eocene deposits of Wyo- 
ming, North Dakota, Colorado, and Utah, Oligocene and Miocene deposits of Alaska, and Miocene deposits in Oregon (Hollick, 1936; MacGinitie, 1969; Hickey, 1977; Wing 1981; Collinson 1992; Fields, 1996). This is the first Miocene macrofossil record from the eastern portion of the continent. A Pliocene occurrence has been recorded from the Citronelle Formation of southern Alabama (Stults and Axsmith, 2015).

Order ALISMATALES R. Br. ex Bercht. and J. Presl, 1820

Family ARACEAE de Jussieu, 1789 Genus LEMNA Linnaeus, 1753

Lemna sp.

Figure 8.1-2

Description. Description of the Hattiesburg Lemna fossils follows traditional terminology for the genus whereby the leaf-like organs are referred to as fronds. However, we recognize that this term does not indicate homology to the fronds of ferns. All the recovered Lemna fossils from the Hattiesburg Formation contain five fronds and measure approximately $4.5-5.0 \mathrm{~mm}$ at their widest point (Figure 8.1). Sunken meristematic zones are observable, but as only one meristematic zone is evident per fossil, it would appear that four of the fronds are daughters. The daughter fronds of each fossil vary in size, some apparently as large as the original mother frond. No roots are visible, but this is likely an artifact of preservation. One impression fossil is particularly informative in showing one primary vein on opposite fronds, the cellular alignment of which is comparable to modern Lemna specimens (Figure 8.2).

Remarks. The entire plant body of Lemna species is highly modified, and true leaves do not exist for this group in any straightforward way and are referred to as fronds (Landolt et al., 1986; Bell, 1991; Bogner, 2009). The flattened plant body of Lemna consist of leaf lamina on the outermost portion, a combination of stem and leaf lamina proximally, and a proximal sunken meristematic zone from whence daughter fronds originate.

Three complete specimens and one partial specimen represent Lemna from the Hattiesburg Formation. They occur in direct association with many fossils of another floating aquatic plant, Salvinia and many examples of a wetland Cyperus sp. The report here of relatively complete vegetative fossils of Lemna is particularly significant, as previous records are known only from relatively poorlypreserved fossils from the early Miocene of the Czech Republic (the Bilina Mine) by Kvaček (2003). Seed records are known from the Oligo- cene through Quaternary of Eurasia (Dorofeev, 1963). Vegetative remains of other Araceae taxa distantly related to Lemna consist of Limnobiophyllum from the Upper Cretaceous and Lower Paleogene of North America and the Miocene Bilina Mine locality in the Czech Republic and Cobbania from the Late Cretaceous of North America and East Asia (Stockey et al., 2007). Limnobiophyllum and Lemna coexisted during the Oligocene and Miocene, but only Lemna survives to the present day (Rothwell et al., 2004; Bogner, 2009).

Order ARECALES Bromhead, 1840

Family ARECACEAE Berchtold and Presl, 1820

Fossil palmate genus PALMACITES Brongniart, 1822 (emend. Read and Hickey, 1972)

Figure 8.3-4

Description. The leaf blade is fan-shaped (coryphoid) and induplicate. The leaf blade is palmate, as the costa does not extend into the leaf blade, rather the leaf segments arise at the petiole apex and extend toward the leaf apex. All palmate leaf segments display a prominent mid-rib. Up to two orders of parallel veins on either side of mid-rib are observable on some specimens as preservation permits. Maximum measurable petiole width is 1.6 $\mathrm{cm}$. Some palmate specimens have attached petioles with well-spaced recurved spines (Figure 8.4).

Fossil costapalmate genus SABALITES Saporta, 1865 (emend. Read and Hickey, 1972)

Figure 8.5

Description. The leaf blade is fan-shaped (coryphoid), induplicate. The leaf is costapalmate, as the costa extends for a distance into blade of leaf (Figure 8.5). Mid-rib of each leaf segment is prominent with up to two orders of parallel veins observable on many specimens. Petioles are unarmed. Maximum measurable petiole width is $2.9 \mathrm{~cm}$.

Remarks. When describing palms, it should be recognized that the term palmate is a categorization on two levels; the first level of distinction is a leaf that is not pinnate (i.e., fan-shaped or coryphoid), and the second level is a comparison regarding the extension of the petiole into the coryphoid leaf blade itself (costapalmate vs. palmate). Costapalmate and palmate fossil leaves are recognized in this collection, primarily using definitions summarized in Read and Hickey (1972). The differential diagnosis is dependent upon the presence of an extended petiole (costa) into the leaf blade from which fused segments emerge at an acute angle vs. a leaf where the costal extension is not present, thus leaf segments originate from a single, centralized area at the top of the petiole. It has long been 

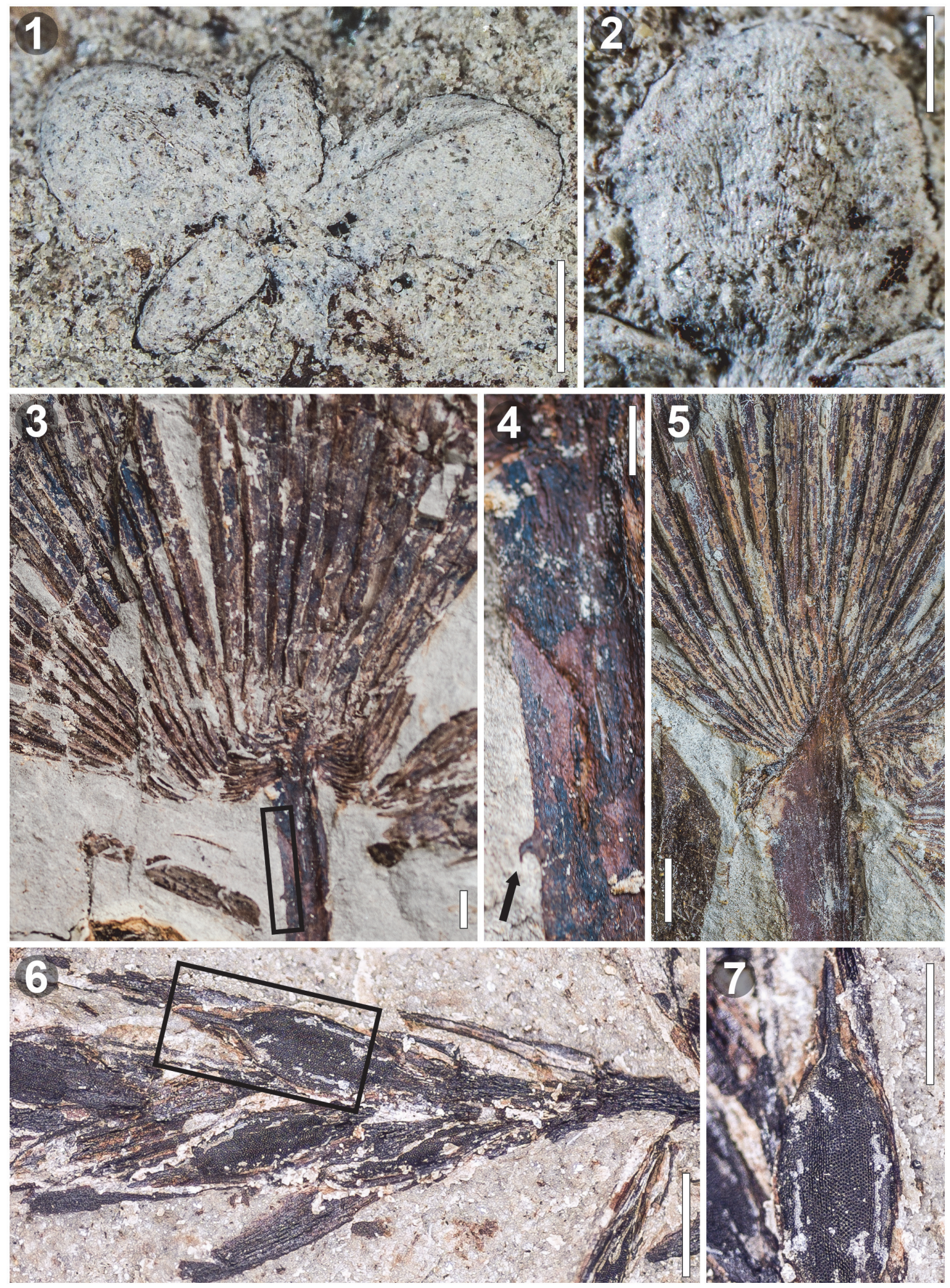

FIGURE 8. Representative monocot families Lemnaceae, Arecaceae, and Cyperaceae. 1, Lemna sp. multiple fronds (MMNS PB-106), scale bar equals $1 \mathrm{~mm}$. 2, Close-up of Figure 8.1 showing detail of single frond. 3, Palmacites sp. showing partial leaf with palmate venation (MMNS PB-107), scale bar equals $1 \mathrm{~cm}$. 4, Close up Figure 8.3 showing tooth on petiole, scale bar equals $5 \mathrm{~mm}$. 5, Sabalities sp. showing partial leaf with costapalmate venation (MMNS PB108), scale bar equals $1 \mathrm{~cm}$. 6, Cyperus sp. with multiple achenes (MMNS PB-109), scale bar equals $1.0 \mathrm{~mm} .7$, Close-up of Figure 6.1 showing detail of the achene, scale bar equals $0.5 \mathrm{~mm}$. 
recognized as impossible to assign extant fan palm leaves to modern genera or species without the additional characters provided by fruit and/or flowers. Correlating fossil fan palm leaves with modern taxa is even more problematical; thus, we use the fossil form genera established for fan palms. However, we realize that any fossil record of palmate leaves with spines on the petioles may require a revision of the form genus Palmacites or establishment of a new fossil form genus, as palmate leaves with spines have not been previously recorded as Palmacites.

Interestingly, a dichotomous key within a field guide of extant palm genera of the Americas (Henderson et al., 1995) lists spines along the petiole as one of the first sub-categorizations (after discriminating between palmate and pinnate leaves) for discerning a genus from the Western Hemisphere. Within the Americas, only five genera match these criteria (i.e., palmate with armed petioles): Acoelorraphe, Serenoa, Copernicia, Brahea, and Washingtonia. From this list, Washingtonia and Brahea are associated with desert climates; additionally, Washingtonia is costapalmate and Brahea is shortly costapalmate. Serenoa is common to the southeastern United States occupying pinelands, prairies, and sand dunes (Henderson et al., 1995) and is a palmate leaf as there is no costal extension into the leaf blade. However, the petiolar teeth of Serenoa are small, fine, sharp, and more closely-spaced teeth than those of the Palmacites fossil. Acoelorraphe occupies swampy, coastal areas of the northern Caribbean while Copernicia is found in savannahs, woodlands and lowland areas of Cuba (Henderson et al., 1995; Dransfield et al., 2008). Both Acoelorraphe and Copernicia are palmate, and both have teeth that appear similar to those of the Hattiesburg Formation Palmacites fossil. Although proposing a direct evolutionary relationship of our fossil to a modern taxon is not yet feasible, it cannot be ruled out that the spinous Palmacites fossil is possibly ancestral to one of these genera, especially considering that the biogeographical history for sub-family Coryphoideae has been a significant factor in its current distributional patterns (Asmussen et al., 2006; Bjorholm et al., 2006).

Recent reviews of coryphoid palm species, including those currently limited to the New World, indicates that most New World genera are unarmed and palmate (Dransfield et al., 2008). As mentioned above, several Hattiesburg fossil specimens of palmate leaves that do not display spines on the petioles fit the original description of $\mathrm{Pal}-$ macites. These could either represent a Miocene precursor to some other modern palmate form or could have lost the spines during preservation and recovery. This review also indicates that a conspicuous costapalmate extension is not representative of most New World genera. Currently, an unarmed, prominently costapalmate leaf would seem to indicate a relationship only with the tribe Sabaleae, genus Sabal. Sabal has 16 species confined to the New World, including the northern Gulf of Mexico Coastal Plain (Dransfield et al., 2008).

Included within the Hattiesburg Formation collection are many palm leaf fragments (currently undeterminable to palmate or costapalmate forms) indicating large dimensions of the original leaf. These include fragments of a palmate leaf with a length of more than $29 \mathrm{~cm}$. Numerous isolated spinous palm petioles also occur in the collection. Isolated palm trunk fragments are common at the site, affirmed by features of the wood anatomy. These will be described in a forthcoming paper.

Palm leaves have been previously reported from the Hattiesburg Formation. Berry (1916a) reported fossils from a location in Forrest County, and Brown (1944) reported palm fragments from a locality on Tallahala Creek. From our data, including numerous records of palm leaves and stems from the Bouie River locality along with previous reports, palms were clearly a dominant feature of this delta-associated plant community. Palm fossils have also been reported from the Catahoula Formation of Mississippi (Berry, 1916c) and from the Alum Bluff locality of Florida (Berry, 1916a; Corbett, 2004). Berry (1916a) argued that the Alum Bluff and Hattiesburg palms represented the same species (Sabalites apalachicolensis), but this is difficult to determine based on the information provided (Corbett, 2004).

Palms have a fossil record extending back to the mid-Cretaceous; however, the fossil record of some common extant palm morphotypes is relatively rare (Read and Hickey, 1972). For example, palm leaves with armed petioles are common among extant taxa (e.g., Licuala, Johannesteijsmannia, Pholidocarpus, and Pritchardiopsisi, and many more) (Dransfield et al., 2008), so it is surprising that there are few such fossil records (e.g., Pan et al., 2006), especially those showing petioles still attached to the leaf blades (Wang et al., 2015) as in the Palmacites specimens described here. Based on our observations of the Bouie River locality fossils, we suggest that palm fossils with armed petioles may be more common than currently thought, as we note that the spines can be 
easily broken off during the collection of the fossils. Also, the matrix does not always clearly spit along a plane on which the petiolar spines occur.

Order POALES Small, 1903

Family CYPERACEAE de Jussieu, 1789

Genus CYPERUS Linnaeus, 1753

Cyperus sp.

Figure 8.6-7

Description. Numerous fossil spikelets, the longest approximately $2 \mathrm{~cm}$, bearing florets distichously arranged on the rachilla are identified as a Cyperus sp. (Figure 8.6). Florets are approximately $3 \mathrm{~mm}$ in length (Figure 8.7). Achenes are biconvex or flattened with surfaces completely covered with evenly spaced, consistently small, rounded projections. Long persistent styles are approximately 1 $\mathrm{mm}$ in length.

Remarks. The apparently deciduous habit of the spikelets and their distichous arrangement along the rachilla indicate affinity with the genus Cyperus, with the caveat that the Cyperaceae are an exceedingly large family, notoriously difficult to identify to lower taxonomic levels in modern examples let alone from fragmentary fossils. However, we suggest that the slightly stipitate, oblong achenes with an apiculate apex (or partly persistent style?) and pitted surface are reminiscent of Cyperus strigosus and relatives, a common species of wetland areas in the southeastern U.S. These fossils occur on slabs with abundant Salvinia and Lemna remains, indicating a relatively quiet, freshwater depositional setting within the Hattiesburg Formation Bouie River locality section.

\section{DISCUSSION}

It has long been realized that the eastern North American Neogene paleobotanical record is poor, especially in comparison with the betterknown western record (Graham, 2010). The new Bouie River flora site described here helps to fill this significant gap in our understanding of North American paleobotany and biogeography. Prior to this study, only five taxa had been reported from the Hattiesburg Formation: Sabalites (an unarmed costapalmate palm), Taxodium, Salix, Ulmus, and Morus/Celtis (Berry, 1916a; Brown, 1944), and most of these were not figured. Here, we identify, describe, and figure 22 taxa. Some of these are identified down to section (i.e., within the genera Quercus, Juglans, and Carya), and some possibly to species (e.g., Osmunda spectabilis).

Several components from this flora are particularly significant from a taxonomic and biogeo- graphical perspective as regional, continental, or even nearly global first records. For example, the first Gulf Coast record of the now endemic Asian genus Sargentodoxa represents a major paleobiogeographic expansion for this genus and supports the Miocene age determination in joint consideration with previous North American records (Tiffney, 1993; Manchester et al., 2009). The Juglans fruit described here is different from those of the two eastern North American extant species (i.e., J. cinerea and J. nigra); therefore, it represents an extinct or extirpated species. We also present some of the only Neogene fern records from eastern North America including Osmunda, the earliest and first fossil evidence of Woodwardia from its current range, and nearly entire plants of the floating fern Salvinia. This flora also makes a key contribution to the fossil record of the floating aroid genus Lemna, as there was only one previous vegetative record, and this was from the Miocene of the Czech Republic (Kvaček, 2003). We also report the earliest macrofossil record of Cercis from eastern North America and describe specimens representing two sections of Quercus that are currently major components of the regional extant forest.

With a few exceptions mentioned above, most of the Bouie River site fossil plants are similar to taxa present in the area today (e.g., Carya, Cyperus, Morus, Platanus, Populus, Taxodium, Salix, and Sambucus), which supports the idea that a generally similar precursor to the current Gulf Coast wetland flora was already established here since at least the middle Miocene. From a qualitative perspective, this suggests that the climate was also similar to now. The presence of abundant palms indicates that the climate was at least warm temperate. This issue will be addressed in a detailed quantitative analysis that will be undertaken once all of the identifications are finalized. However, like the late Pliocene Citronelle flora of Alabama, the Hattiesburg flora was relatively poor in Pinus (only pollen has been found to date from the Bouie River site) compared to this region today, which could indicate somewhat drier conditions than at present (Stults et al., 2010).

\section{CONCLUSION}

The newly recognized Bouie River site of the Hattiesburg Formation has substantially increased our knowledge of the middle Miocene floras of the Gulf of Mexico Coastal Plain. Where previously only five taxa had been recognized, 22 are now acknowledged, including "exotics" and several 
other taxa, which had no previous Miocene record from eastern North America. As additional older and younger sites are studied, the Bouie River flora will be an important window into developing a broader view of the evolution of the extant Gulf Coast flora. However, it is already apparent that the Bouie River site fossils, along with those of the Citronelle Formation (Stults and Axsmith, 2011, 2015) and other sites under study, support the concept of an early establishment of a flora generally similar to that of the modern Gulf Coast, but with the presence of several "exotic" taxa that subsequently disappear from North America during the late Pliocene (Graham, 2010). This also suggests that climates through this interval were similar to today and were relatively stable.

Although many of the plant fossils are described here in considerable detail, we still consider this research preliminary overall. Additional taxa are still being found with nearly every visit to the site, indicating that much more diversity awaits discovery. In addition, some of the taxa, such as the fern Salvinia and the palms, merit additional study as dedicated papers. Palynological analysis, which is yielding evidence of additional taxa not yet represented in the megafossil record, is ongoing. Stratigraphic work is also refining the formational boundaries and ages, which will allow better temporal constraint for Gulf Coast fossil floras (Dock- ery and Thomson, 2016). In any case, it is becoming increasingly clear that the supposed paucity of Neogene plant megafossil sites in the southeastern USA compared to the well-known succession in western states may be at least in part due to poor exposure and historically inadequate prospecting and study.

\section{ACKNOWLEDGMENTS}

We would especially like to thank K. Spencer for kindly granting us permission to collect specimens on her property. We are grateful to our reviewers, S. Manchester and two anonymous referees for their helpful comments. We are also grateful to the following researchers who offered helpful information at various stages of this project: J.R. Carter, J. Fisher, R. Moran, and R. Naczi. We would like to thank everyone who helped collect and curate specimens: J. Axsmith, G. Brown, A. Calidris, C.L. Hernandez, A. Holbrook, J. Lamb, the late C. "Smoot" Major, M. McWhorter, B. Morris, J. Price, B. Purdy, T. Samarakoon, and T. Sevick. Curatorial assistance was provided by G. Phillips of the Mississippi Museum of Natural Science. Aspects of this research were supported by NSF grant EAR-0642032 (to BJA) and NSF grant 1203684 (to MHA).

\section{REFERENCES}

Angiosperm Phylogeny Group IV. 2016. An update of the Angiosperm Phylogeny Group classification for the orders and families of flowering plants: APG IV. Botanical Journal of the Linnean Society, 181:1-20. https://doi.org/10.1111/boj.12385

Aradhya, M.K., Potter, D., and Simon, C.J. 2005. Origin, evolution, and biogeography of Juglans: a phylogenetic perspective. Acta Horticulturae, 705:85-94. https://doi.org/10.17660/ actahortic.2005.705.8

Arana, M.D. and Ponce, M. 2015. Osmundaceae en Argentina, Paraguay y Uruguay. Darwiniana, 3:27-37.

Asmussen, C.B., Dransfield, J., Deickmann, V., Barfod, A.S., Pintaud, J.C., and Baker, W.J. 2006. A new subfamily classification of the palm family (Arecaceae): evidence from plastid DNA phylogeny. Botanical Journal of the Linnean Society, 151:15-38. https://doi.org/10.1111/ j.1095-8339.2006.00521.x

Aulenback, K.R. and LePage, B.A. 1998. Taxodium wallisii sp. nov: first occurrence of Taxodium from the Upper Cretaceous. International Journal of Plant Sciences, 159:367-390. https:// doi.org/10.1086/297558

Bartling, F.G. 1830. Ordines Naturales Plantarum. Deiterich, Göttingen.

Bell, A.D. 1991. An Illustrated Guide to Flowering Plant Morphology. Oxford University Press, Oxford.

Berry, E.W. 1916a. The physical conditions and age indicated by the flora of the Alum Bluff Formation. United States Geological Survey Professional Paper, Report, 98:41-59. https:// doi.org/10.5962/bhl.title.7797 
Berry, E.W. 1916b. The flora of the Citronelle Formation. United States Geological Survey Professional Paper, 98:167-208.

Berry, E.W. 1916c. The flora of the Catahoula Sandstone. United States Geological Survey Professional Paper, 98-M:227-243.

Berry, E.W. 1925. A new Salvinia from the Eocene. Torreya, 25:116-118.

Berry, E.W. 1926. Pleistocene plants from North Carolina. United States Geological Survey Professional Paper, 140C:97-119.

Beuchler, W.K. 2014. Variability of venation patterns in extant genus Salix: Implication for fossil taxonomy. PaleoBios 30:89-104.

Bierhorst, D.W. 1971. Morphology of Vascular Plants. Macmillan, New York.

Bjorholm, S., Svenning, J-C., Baker, W.J., Skov, F., and Balslev, H. 2006. Historical legacies in the geographical diversity patterns of New World palm (Arecaceae) subfamilies. Botanical Journal of the Linnean Society, 151:113-125. https://doi.org/10.1111/j.10958339.2006.00527.x

Bogner, J. 2009. The free-floating aroids (living and fossil). Zitteliana, 48/49:113-128.

Bomfleur, B., McLoughlin, S., and Vajda, V. 2014. Fossilized nuclei and chromosomes reveal 180 million years of genomic stasis in royal ferns. Science, 343:1376-1377. https://doi.org/ 10.1126/science.1249884

Bouchenak-Khelladi, Y., Slingsby, J.A., Verboom, G.A., and Bond, W.J. 2014. Diversification of $\mathrm{C}_{4}$ grasses (Poaceae) does not coincide with their ecological dominance. American Journal of Botany, 101:300-307. https://doi.org/10.3732/ajb.1300439

Bromhead, E.F. 1838. An attempt to ascertain characters of the botanical alliances. The Edinburgh New Philosophical Journal, 24:408-419.

Bromhead, E.F. 1840. Remarks on the botanical system of Professor Perleb. Magazine of Natural History, and Journal of Zoology, Botany, Mineralogy, Geology, and Meteorology, 4:329-338.

Brongniart, A.T. 1822. Sur la Classification et la Distribution des Végétaux fossiles. Vol. 8. Impr. de A. Belin, Paris.

Brown, G.F. 1944. Geology and ground-water resources of the Camp Shelby area. Mississippi State Geological Survey Bulletin, 58:1-72.

Brown, R. 1821. Lardizabalaceae. Transactions of the Linnean Society of London. London, $13: 212$.

Camus, A. 1938. Les Chênes Monographie du Genre Quercus. Lechavalier, Paris.

Chanderbali, A.S., van der Werff, H., and Renner, S.S. 2001. Phylogeny and historical biogeography of Lauraceae: Evidence from the chloroplast and nuclear genomes. Annals of the Missouri Botanical Garden, 88:104-134. https://doi.org/10.2307/2666133

Chase, M.W. and Reveal, J.L. 2009. A phylogenetic classification of the land plants to accompany APG III. Botanical Journal of the Linnean Society, 161:122-127. https://doi.org/ 10.1111/j.1095-8339.2009.01002.x

Chen, D., Zhang, D., Larsen, S.S., and Vincent, M.A. 2010. Cercis, p. 5-6. In Wu, Z.Y., Raven, P.H., and Hong, D.Y. (eds.), Flora of China, vol. 10 (Fabaceae). Missouri Botanical Garden Press, St. Louis.

Chen, J.-H., Sun, H., and Yang, Y.-P. 2008. Comparative morphology of leaf epidermis of Salix (Salicaceae) with special emphasis on sections Lindleyanae and Retusae. Botanical Journal of the Linnean Society, 157:311-322. https://doi.org/10.1111/j.1095-8339.2008.00809.x

Christophel, D.C., Kerrigan, R., and Rowett, A. 1996. The use of cuticular features in the taxonomy of the Lauraceae. Annals of the Missouri Botanical Garden, 83:419-432. https:// doi.org/10.2307/2399871

Cobb, B., Lowe, C., and Farnsworth, E. 2005. Peterson Field Guide to Ferns: Northeastern and Central North America (second edition). Houghton Mifflin Company, New York.

Collinson, M.E. 1991. Diversification of modern heterosporous pteridophytes, p. 119-150. In Blackmore, S. and Barnes, S.H. (eds.), Pollen and Spores: Patterns of Diversification. The Systematics Association Special, volume 44. Oxford University Press, New York.

Collinson, M.E. 1992. The early fossil history of Salicaceae: a brief review. Proceedings of the Royal Society of Edinburgh, 96B:155-167. https://doi.org/10.1017/s0269727000007521

Collinson, M.E. 1996. What use are fossil ferns? -20 years on: With a review of the fossil of extant pteridophyte families and genera, p. 349-304. In Camus, J.M., Gibb, M., and Johns, R.J. (eds.), Pteridology in Perspective. Royal Botanical Gardens Kew, London. 
Collinson, M.E. 2001. Cainozoic ferns and their distribution. Brittonia, 53:173-235. https://doi.org/ $10.1007 /$ bf02812700

Collinson, M.E., Kvaček, Z., and Zastawniak, E. 2001. The aquatic plants Salvinia (Salviniales) and Limniobiophyllum (Arales) from the Late Miocene flora of Sonica (Poland). Acta Palaeobotanica, 41:253-282.

Corbett, S.L. 2004. The Middle Miocene Alum Bluff Flora, Liberty County, Florida. Unpublished MS Thesis, University of Florida, Gainesville, Florida, USA.

Cranfill, R.B. 1993. Woodwardia, p. 226-227. In Flora of North America Editorial Committee (eds.), Flora of North America North of Mexico, vol. 2 (Pteridophytes and Gymnosperms). Oxford University Press, New York and Oxford.

Crepet, W.L. and Daghlian, C.P. 1980. Castaneoid inflorescences from the Middle Eocene of Tennessee and the diagnostic value of pollen (at the subfamily level) in the Fagaceae. American Journal of Botany, 67:739-757. https://doi.org/10.1002/j.15372197.1980.tb07704.x

Cronquist, A., Takhtajan, A., and Zimmermann, W. 1966. On the higher taxa of Embryobionta. Taxon, 15:129-134.

Daghlian, C.P. and Crepet, W.L. 1983. Oak catkins, leaves and fruits from the Oligocene Catahoula Formation and their evolutionary significance. American Journal of Botany, 70:639-649. https://doi.org/10.2307/2443119

Datwyler, S.L. and Weiblen, G.D. 2004. On the origin of the fig: Phylogenetic relationships of Moraceae from ndhF sequences. American Journal of Botany, 91:767-777. https://doi.org/ 10.3732/ajb.91.5.767

de Candolle, A.C.P. 1864. Juglandaceae, p. 134-146. In de Candolle, A. (ed.), Prodromus Systematis Naturalis Regni Vegetabilis, vol. 16, part 2. Sumptibus Victoris Masson et Filii, Paris.

de Candolle, A.P. 1818. Versuch über die Arzneikräfte der Pflanzen. Heinrich Remigius Sauerländer, Paris.

de Jussieu, A.L. 1789. Genera Plantarum. Herissant and Barrois, Paris.

Dockery, III, D.T. and Thompson, D.E. 2016. The Geology of Mississippi. University Press of Mississippi, Jackson, Mississippi.

Dode, L.A. 1909a. Contribution à l'étude du genre Juglans. Bulletin de la Societé Dendrologique de France, 11:140-166.

Dode, L.A. 1909b. Contribution à l'étude du genre Juglans. Bulletin de la Societé Dendrologique de France, 13:165-213.

Dorofeev, P.I. 1963. The Tertiary Floras of Western Siberia. Izd-vo Akademii nauk SSSR, Moscow.

Dransfield, J., Uhl, N.W., Asmussen, C.B., Baker, W.J., Harley, M.M., and Lewis, C.E. 2008. Genera Palmarum, the Evolution and Classification of Palms. Kew Publishing, Royal Botanic Gardens, Kew.

Drinnan, A., Crane, P., Friis, E., and Pedersen, K. 1990. Lauraceous flowers from the Potomac Group (mid-Cretaceous) of Eastern North America. Botanical Gazette, 151:370-384. https:// doi.org/10.1086/337838

Dumortier, B.C.J. 1829. Analyse des Familles des Plantes: avec l'indication des principaux genres qui s'y rattachent. J. Casterman, Tournay. https://doi.org/10.5962/bhl.title.48702

Eckenwalder, J.E. 1980. Foliar heteromorphism in Populus (Salicaceae), a source of confusion in the taxonomy of Tertiary leaf remains. Systematic Botany, 5:366-383. https://doi.org/ $10.2307 / 2418518$

Eklund, H. and Kvaček, J. 1998. Lauraceous inflorescences and flowers from the Cenomanian of Bohemia (Czech Republic, Central Europe). International Journal of Plant Sciences, 159:668-686. https://doi.org/10.1086/297585

Ellis, B., Daly, D.C., Hickey, L.J., Mitchell, J.D., Johnson, K.R., Wilf, P., and Wing, S.L. 2009. Manual of Leaf Architecture. Comstock Publishing Associates: Ithaca, New York.

Engler, H.G.A. 1892. Syllabus der Vorlesungen über Specielle und MedicinischPharmaceutische Botanik. Gebrüder Borntraeger, Berlin.

Eriksson, T. and Donoghue, M.J. 1997. Phylogenetic relationship of Sambucus and Adoxa (Adoxaceae) based on nuclear ribosomal ITS sequences and preliminary morphological data. Systematic Botany, 22:555-573. https://doi.org/10.2307/2419828

Farjon, A. 2005. A Monograph of Cupressaceae and Sciadopitys. Royal Botanical Gardens, Kew. 
Fields, P.F. 1996. The Succor Creek Flora of the Middle Miocene Sucker Creek Formation, Southwestern Idaho and Eastern Oregon: Systematics and Paleoecology. Unpublished PhD Dissertation, Michigan State University, East Lansing, Michigan, USA.

Foster, V.M. 1941. Geology, p. 13-59. In Foster, V.M. and McCutcheon, T.E. (eds.), Forrest County Mineral Resources. Mississippi Geological Survey Bulletin 44. University of Mississippi, Oxford.

Frank, A.B. 1877. Polypodioideae, p. 1453. In Leunis, J. (ed.), Synopsis der Pflanzenkunde, Zweite Auflage. Hahn'sche Buchhandlung, Hanover.

Gaudichaud-Beaupré, C. 1835. Moraceae, p. 13. In Trinius, C.B. (ed.), Genera Plantarum ad Familias Suas Redacta. Impensis Academiae Imperialis Scientiarum, Petrapoli.

Godfrey, R.K. 1988. Trees, Shrubs, and Woody Vines of Northern Florida and Adjacent Georgia and Alabama. The University of Georgia Press, Athens, Georgia.

Gong, F., Karsai, I., and Liu, Y.S.C. 2010. Vitis seeds (Vitaceae) from the late Neogene Gray fossil site, northeastern Tennessee, USA. Review of Palaeobotany and Palynology, 162:7183. https://doi.org/10.1016/j.revpalbo.2010.05.005

Gray, A. 1856. Manual of the Botany of the Northern United States, Including Virginia, Kentucky, and All East of the Mississippi: Arranged According to the Natural System. Second Edition. Ivison, Phinney \& Company, Chicago.

Graham, A. 2010. A Natural History of the New World: The Ecology and Evolution of Plants in the Americas. University of Chicago Press. https://doi.org/10.7208/chicago/ 9780226306827.001 .0001

Henderson, A., Galeano, G., and Bernal, R. 1995. Field Guide to the Palms of the Americas. Princeton University Press, Princeton, New Jersey.

Hewitson, W. 1962. Comparative morphology of the Osmundaceae. Annals of the Missouri Botanical Garden, 49:57-93. https://doi.org/10.2307/2394741

Hickey, L.J. 1977. Stratigraphy and paleobotany of the Golden Valley Formation (early Tertiary) of western North Dakota. GSA Memoirs, 150:1-29.

Hickey, L.J. and Wolfe, J.A. 1975. The bases of angiosperm phylogeny: Vegetative morphology. Annals of the Missouri Botanical Garden, 62:538-589.

Hollick, A. 1892. Palaeobotany of the Yellow Gravel at Bridgeton, N. J. Bulletin of the Torrey Botanical Club, 19:330-333. https://doi.org/10.2307/2475960

Hollick, A. 1936. The Tertiary Floras of Alaska. United States Geological Survey Professional Paper, 182:1-324

Huang, Y., Jacques, F.M.B., Liu, Y.-S., Su, T., Xing, Y., Xiao, X., and Zhou, Z. 2012. New fossil endocarps of Sambucus (Adoxaceae) from the Upper Pliocene in SW China. Review of Palaeobotany and Palynology, 171:152-163. https://doi.org/10.1016/j.revpalbo.2011.11.008

Huang, Y-J., Liu, Y-S. and Zavada, M. 2014. New fossil fruits of Carya (Juglandaceae) from the latest Miocene to earliest Pliocene in Tennessee, eastern United States. Journal of Systematics and Evolution, 52:508-520. https://doi.org/10.1111/jse.12085

Hulbert, R. and Whitmore, F.C. 2006. Late Miocene mammals from the Mauvilla Local Fauna, Alabama. Bulletin of the Florida Museum of Natural History, 46:1-28.

Imaichi, R. and Kato, M. 1992. Comparative leaf development of Osmunda lancea and O. japonica (Osmundaceae): Heterochronic origin of rheophytic stenophylly. Botanical Magazine Tokyo, 105:199-213. https://doi.org/10.1007/bf02489415

Jacono, C.C., Davern, T.R., and Center, T.D. 2001. The adventive status of Salvinia minima and S. molesta in the southern United States and the related distribution of the weevil Cyrtobagous salviniae. Castanea, 66:214-226.

Jia, H. and Manchester, S.R. 2014. Fossil leaves and fruits of Cercis L. (Leguminosae) from the Eocene of Western North America. International Journal of Plant Sciences, 175:601-612. https://doi.org/10.1086/675693

Kartesz, J.T. 2015. The Biota of North America Program (BONAP). North American Plant Atlas, Chapel Hill, N.C. http://bonap.net/napa

Keller, A.S., Morris, R.H., and Detterman, R.L. 1961. Geology of the Shaviovik and Sagavanirktok Rivers Region, Alaska. United States Geological Survey Professional Paper, 303D. United States Geological Survey, Reston.

Knobloch, E. and Mai, D.H. 1986. Monographie der Fruchte und Samen in der Kreide von Mitteleurope. Rozpravy Ústredního Ústavu Geologického, 47:1-219. 
Kunzmann, L., Kvaček, Z., Mai, D.H., and Walther, H. 2009. The genus Taxodium (Cupressaceae) in the Palaeogene and Neogene of Central Europe. Review of Palaeobotany and Palynology, 153:153-183. https://doi.org/10.1016/j.revpalbo.2008.08.003

Kvaček, Z. 2003. Aquatic angiosperms of the Early Miocene Most Formation of North Bohemia (Central Europe). Courier Forschungsinstitut Senckenberg, 241:255-279.

Landolt, E., Lüönd, A., and Kandeler, R. 1986. Biosystematic Investigations in the Family of Duckweeds (Lemnaceae). Geobotanischen Institut der ETH, Zürich.

Lestiboudois, T.G. 1826. Botanographie Élémentaire. Roret, Paris.

Lindley, J. 1836. Natural System of Botany: or, a Systematic View of the Organization, Natural Affinities, and Geographical Distribution of the Whole Vegetable Kingdom Together with the Uses of the Most Important Species in Medicine, the Arts, and Rural and Domestic Economy. Edition 2. Longman, Rees, Orme, Brown, Green, and Longman, London. https://doi.org/ 10.5962/bhl.title.130142

Linnaeus, C. 1753. Species Plantarum. Impensis Laurentii Salvius, Stockholm.

Little, E.L., Jr. 1977. Atlas of United States Trees, Volume IV: Minor Eastern Hardwoods. United States Department of Agriculture Miscellaneous Publication 1342. United States Department of Agriculture, Washington, D.C.

Loudon, J.C. 1830. Loudons Hortus Britannicus: A Catalogue of All the Plants Indigenous, Cultivated In, or Introduced to Britain. Part I. The Linnaean Arrangement: Part II. The Jussieuean Arrangement. Longman, Rees, Orme, Brown, and Green, London. https:// doi.org/10.5962/bhl.title.10320

Löve, Á. and Löve, D. 1977. New combinations in ferns. Taxon, 26:324-326. https://doi.org/ $10.2307 / 1220575$

Mai, Q.-W., Vikulin, S.V., Li, C.-S., and Wang, Y.-F. 2013. Details of compressions of Glyptostrobus (Cupressaceae s.I.) from the Eocene of Fushun, NE China. Journal of Systematics and Evolution, 51:601-608. https://doi.org/10.1111/jse.12035

MacGinitie, H.D. 1941. A Middle Eocene flora from the central Sierra Nevada. Carnegie Institution of Washington Publication, 534:1-178.

MacGinitie, H.D. 1953. Fossil plants of the Florissant beds, Colorado. Carnegie Institute of Washington Publication, 599:1-198.

MacGinitie, H.D. 1969. The Eocene Green River flora of northwestern Colorado and northeastern Utah. University of California Publications in Geological Sciences, 83:1-203.

Manchester, S.R. 1987. The fossil history of the Juglandaceae. Monographs in Systematic Botany, Missouri Botanical Garden, 21:1-137.

Manchester, S.R. 1994. Fruits and seeds of the Middle Eocene Nut Beds Flora, Clarno Formation, Oregon. Palaeontographica Americana, 58:1-205.

Manchester, S.R. 1999. Relationships of North American Tertiary floras. Annals of the Missouri Botanical Garden, 86:472-522. https://doi.org/10.2307/2666183

Manchester, S.R. 2001. Update on the megafossil flora of Florissant, Colorado, p. 137-161. In Evanoff, E., Gregory-Wodzicki, K.M., and Johnson, K.R. (eds.), Fossil Flora and Stratigraphy of the Florissant Formation, Colorado. Denver Museum of Nature \& Science, Denver, Colorado.

Manchester, S.R., Judd, W.S., and Handley, B. 2006. Foliage and fruits of early poplars (Salicaceae): Populus from the Eocene of Utah, Colorado, and Wyoming. International Journal of Plant Sciences, 167:897-908. https://doi.org/10.1086/503918

Manchester, S.R., Chen, Z.-D., Lu, A.-M., and Uemura, K. 2009. Eastern Asian endemic seed plant genera and their paleogeographic history throughout the Northern Hemisphere. Journal of Systematics and Evolution, 47:1-42. https://doi.org/10.1111/j.1759-6831.2009.00001.x

Manning, W.E. 1978. The classification within the Juglandaceae. Annals of the Missouri Botanical Garden, 65:1058-1087. https://doi.org/10.2307/2398782

Manos, P.S. 1997. Quercus sect. Protobalanus, p. 468. In Flora of North America Editorial Committee (ed.), Flora of North America North of Mexico, vol. 3. Oxford University Press, New York and Oxford.

Marshall, H. 1785. Arbustrum Americanum: The American Grove, or, an Alphabetical Catalogue of Forest Trees and Shrubs, Natives of the American United States, Arranged According to the Linnaean System. J. Crukshank, Philadelphia. https://doi.org/10.5962/bhl.title.68506

Martinov, I.I. 1820. Tekhno-Botanicheskī Slovar, na Latinskom i Rossīıkom lâzykakh. (Publisher unknown), Saint Petersburg. (In Latin and Russian) https://doi.org/10.5962/bhl.title.96260 
Maslova, N.P. 1996. The genus Platanus L. (Platanaceae Dumortier) in the Palaeocene of Kamchatka. Paleontological Journal, 31:208-214.

McCartan, L., Tiffney, B.H., Wolfe, J.A., Ager, T.A., Wing, S.L., Sirkin, L.A., Ward, L.W., and Brooks, J. 1990. Late Tertiary assemblage from upland gravel deposits of the southern Maryland Coastal Plain. Geology, 18:311-314. https://doi.org/10.1130/00917613(1990)018\%3C0311:Itfafu\%3E2.3.co;2

Metzgar, J.S., Skog, J.E., Zimmer, E.A., and Pryer, K.M. 2008. The paraphyly of Osmunda is confirmed by phylogenetic analysis of seven plastid loci. Systematic Botany, 33:31-36. https:/ /doi.org/10.1600/036364408783887528

Meyer, E. 1839. Preussens Pflanzengattungen. Gräfe und Unzer, Königsberg.

Miller, C.N. 1967. Evolution of the fern genus Osmunda. Contributions from the Museum of Paleontology, University of Michigan, 21:139-203.

Miller, P. 1754. The Gardeners Dictionary. Rivington, London. https://doi.org/10.5962/ bhl.title.20764

Mirbel, C.F.B. 1815. Ėlements de Physiologie Végétale et de Botanique. Chez Magimal, Paris. https://doi.org/10.5962/bhl.title.110802

Nepal, M.P. and Ferguson, C.J. 2012. Phylogenetics of Morus (Moraceae) inferred from ITS and trnL-trnF sequence data. Systematic Botany, 37:442-450. https://doi.org/10.1600/ $036364412 \times 635485$

Newman, E. 1844. A History of British Ferns. J. van Voorst, London. https://doi.org/10.1080/ 037454809495214

Nixon, K.C. 1993. Infrageneric class of Quercus (Fagaceae) and typification of sectional names. Annals of Forest Science, 50:255-345. https://doi.org/10.1051/forest:19930701

Nixon, K.C. 1997. Fagaceae, p. 436-506. In Flora of North America Editorial Committee (ed.), Flora of North America North of Mexico, Vol. 3. Oxford University Press. New York and Oxford.

Nixon, K.C. and Muller, C.H. 1997.Quercus sect. Quercus, p. 471-506. In Flora of North America Editorial Committee (ed.), Flora of North America North of Mexico, Vol. 3. Oxford University Press. New York and Oxford.

Nuttall, T. 1818. The Genera of North American Plants and a Catalogue of the Species, to the Year 1817. G. Heartt. Philadelphia. https://doi.org/10.5962/bhl.title.24647

Pan, A.D., Jacobs, B.F., Dransfield, J., and Baker, W.J. 2006. The fossil history of palms (Arecaceae) in Africa and new records from the Late Oligocene (28-27 Mya) of northwestern Ethiopia. Botanical Journal of the Linnean Society, 151:69-81. https://doi.org/10.1111/j.10958339.2006.00523.x

Phipps, C.J., Taylor, T.N., Taylor, E.L., Cuneo, N.R., Boucher, L.D., and Yao, X. 1998. Osmunda (Osmundaceae) from the Triassic of Antarctica: an example of evolutionary stasis. American Journal of Botany, 85:888-895. https://doi.org/10.2307/2446424

Pigg, K.B. and Rothwell, G.W. 2001. Anatomically preserved Woodwardia virginica (Blechnaceae) and a new filicalean fern from the middle Miocene Yakima Canyon Flora of Central Washington, USA. American Journal of Botany, 88:777-787. https://doi.org/10.2307/ 2657030

Pigg, K.B., Devore, M.L., and Wehr, W.C. 2006. Filicalean ferns from the Tertiary of western North America: Osmunda L. (Osmundaceae: Pteridophyta) and onocleoid forms (Filicales: Pteridophyta). Fern Gazette, 17:279-286.

Prothero, D. and Manning, E. 1987. Miocene rhinoceroses from the Texas Gulf Coastal Plain. Journal of Paleontology, 61:388-423. https://doi.org/10.1017/s0022336000028559

Read, R.W. and Hickey, L.J. 1972. A revised classification of fossil palm and palm-like leaves. Taxon, 21:129-137. https://doi.org/10.2307/1219237

Rehder, A. and Wilson, E.H. 1913. Plantae Wilsonianae an Enumeration of the Woody Plants Collected in China for the Arnold Arboretum of Harvard University, MA. The University Press, Cambridge, Massachusetts. https://doi.org/10.5962/bhl.title.33536

Reinke J. 1876. Beiträge zur Anatomie der an Laubblättern, besonders an den Zähnen derselbem vorkommenden Secretions-organe. Jahrbuch für Wissenschaftliche Botanik, 10:119-178.

Reveal, J.L. 1992. Validation of subclass and superordinal names in Magnoliophyta. Novon, 2:235-237.

Reveal, J.L. 2012. An outline of a classification scheme for extant flowering plants. Phytoneuron, 37:1-221. 
Richard, L.C.M. 1810. Note sur les Plantes dites Conifères. Annales du Museum National d'Histoire Naturelle, 16:296-299.

Rothwell, G.W., Van Atta, M.R., Ballard, Jr., H.E., and Stockey, R.A. 2004. Molecular and phylogenetic relationships among Lemnaceae and Araceae using the chloroplast trnL, trnF intergenic spacer. Molecular Phylogenetics and Evolution, 30:378-385. https://doi.org/ 10.1016/S1055-7903(03)00205-7

Saporta, G. 1865. Études sur la vegetation du sud-est de la France a l'époque tertiare. Annales des Sciences Naturelles (Botanique), 5:5-152.

Séguier, J.F. 1754. Planta Veronenses, vol. 3. (Publisher unknown), Veronae.

Small, J.K. 1903. Flora of the Southeastern United States. Hafner, New York.

Smiley, C.J. and Rember, W.C. 1985. Composition of the Miocene Clarkia Flora, p. 175-184. In Smiley, C.J. (ed.), Late Cenozoic History of the Pacific Northwest. Pacific Division of the American Association for the Advancement of Science, San Francisco.

Smith, A.R., Pryer, K.M., Schuettpelz, E., Korall, P., Schneider, H., and Wolf, P.G. 2006. A classification for extant ferns. Taxon, 55:705-731. https://doi.org/10.2307/25065646

Smith, H.V. 1938. Some new and interesting Late Tertiary plants from Sucker Creek, IdahoOregon boundary. Bulletin of the Torrey Botanical Club, 65:557-564. https://doi.org/10.2307/ 2480794

Smith, J.E. 1793. Tentamen botanicum de filicum generibus dorsiferarum.Mémoires del'Académie Royal des Sciences de Turin, 5:401-422.

Stockey, R.A., Rothwell, G.W., and Johnson, K.R. 2007. Cobbania corrugata gen. et. comb. nov. (Araceae): A floating aquatic monocot from the Upper Cretaceous of Western North America. American Journal of Botany, 94:609-624. https://doi.org/10.3732/ajb.94.4.609

Stults, D. 2003. Paleoecological Analysis of the Citronelle Formation from the Paleoflora of Three Sites in Southwest Alabama. Unpublished MS Thesis, University of South Alabama, Mobile, Alabama, USA.

Stults, D.Z. and Axsmith, B.J. 2011. Filling the gaps in the Neogene plant fossil record of eastern North America: New data from the Pliocene of Alabama. Review of Palaeobotany and Palynology,167:1-9. https://doi.org/10.1016/j.revpalbo.2011.07.004

Stults, D.Z and Axsmith, B.J. 2015. New plant fossil records and paleoclimate analysis of the late Pliocene Citronelle Formation flora U.S. Gulf Coast. Palaeontologia Electronica 18.3.47A:135. https://doi.org/10.26879/550 https://palaeo-electronica.org/content/2015/1318-citronelle-flora-climate

Stults, D.Z., Axsmith, B.J., and Liu, Y.S.C. 2010. Evidence of white pine (Pinus subgenus Strobus) dominance from the Pliocene northeastern Gulf of Mexico Coastal Plain. Palaeogeography, Palaeoclimatology, Palaeoecology, 287:95-100. https://doi.org/ 10.1016/j.palaeo.2010.01.021

Stults, D.Z., Wagner-Cremer, F., and Axsmith, B.J. 2011. Atmospheric paleo- $\mathrm{CO}_{2}$ estimates based on Taxodium distichum (Cupressaceae) fossils from the Miocene and Pliocene of Eastern North America. Palaeogeography, Palaeoclimatology, and Palaeoecology, 309:327332. https://doi.org/10.1016/j.palaeo.2011.06.017

Thompson, R.S., Anderson, K.H., and Bartlein, P.J. 1999. Atlas of relation between climate parameters and distributions of important trees and shrubs in North America hardwoodsUnited States Geological Survey Professional Paper, 1650-B:1-423.

Tidwell, W.D. and Ash, S.R. 1994. A review of selected Triassic to Early Cretaceous ferns. Journal of Plant Research, 107:417-442. https://doi.org/10.1007/bf02344066

Tiffney, B. 1985. The Eocene North Atlantic land bridge: Its importance in Tertiary and modern phytogeography of the Northern Hemisphere. Journal of the Arnold Arboretum, 66:3-94. https://doi.org/10.5962/bhl.part.13183

Tiffney, B. 1993. Fruits and seeds of the Tertiary Brandon Lignite. VII. Sargentodoxa (Sargentodoxaceae). American Journal of Botany, 80:517-523. https://doi.org/10.1002/ j.1537-2197.1993.tb13834.x

Tiffney, B. 1994. Re-evaluation of the age of the Brandon Lignite (Vermont, USA) based on plant megafossils. Review of Palaeobotany and Palynology, 82:299-315. https://doi.org/10.1016/ 0034-6667(94)90081-7

Underwood, L.M. 1903. Notes on southern ferns. Torreya, 3:17.

Vavrek, M.J., Stockey, R.A., and Rothwell, G.W. 2006. Osmunda vancouverensis sp. nov. (Osmundaceae), permineralized fertile frond segments from the Lower Cretaceous of British 
Columbia, Canada. International Journal of Plant Sciences, 167:631-637. https://doi.org/ 10.1086/500994

von Berchtold, F. and Presl, J.S. 1820. O Prirozenosti Rostlin. Krala Wiljma Endersa, Prague.

Wang, L., Xu, Q.-Q., and Jin, J.-H. 2014. A reconstruction of the fossil Salvinia from the Eocene of Hainan Island, South China. Review of Palaeobotany and Palynology, 203:12-21. https:// doi.org/10.1016/j.revpalbo.2013.12.005

Wang, Q.J., Ma, F.J., Dong, J.L., Yang, Y., Jin, P.H., and Sun, B.N. 2015. Coryphoid palms from the Oligocene of China and their biogeographical implications. Comptes Rendus Palevol, 14:263-279. https://doi.org/10.1016/j.crpv.2015.03.005

Watson, L. and Dallwitz, M.J. 1992+. The families of flowering plants: Descriptions, illustrations, identification, and information retrieval. www.delta-intkey.com (accessed June 1, 2016).

Weber, B. 1978. Contribution à l'étude morphologique des feuilles de Salix L. Bulletin de la Société Botanique Suisse, 88:72-119.

Wilkinson, H.P. 2007. Leaf teeth in certain Salicaceae and 'Flacourtiaceae.' Botanical Journal of the Linnean Society, 155:241-256. https://doi.org/10.1111/j.1095-8339.2007.00695.x

Willdenow, C.L. 1810. Species Plantarum, Editio Quarta. Impensis G.C. Nauk, Berlin.

Wing, S.L. 1981. A Study of the Paleoecology and Paleobotany in the Willwood Formation (early Eocene), Wyoming. Unpublished PhD Dissertation. Yale University, New Haven, Connecticut, USA

Wolfe, J.A. 1973. Fossil forms of the Amentiferae. Brittonia, 25:334-355. https://doi.org/10.2307/ 2805639

Wolfe, J.A. 1975. Some aspects of plant geography of the Northern Hemisphere during the Late Cretaceous and Tertiary. Annals of the Missouri Botanical Garden, 62:264-279. https:// doi.org/10.2307/2395198

Zhang, J.-B., Li, R-Q., Xiang, X.-G., Manchester, S.R., Lin, L., Wang, W., Wen, J., and Chen, Z.D. 2013. Integrated fossil and molecular data reveal the biogeographic diversification of the Eastern Asian-Eastern North American disjunct hickory genus (Carya Nutt.). PloS ONE 8(7):e70449. https://doi.org/10.1371/journal.pone.0070449

Zheng, W. 1983. On the significance of Pacific intercontinental discontinuity. Annals of the Missouri Botanical Garden, 70:577-590. https://doi.org/10.2307/2398977 